\title{
Tourism and heritage in the enhancement of Tianjin
}

\author{
Bruno Chauffert-Yvart ${ }^{1}$, Françoise Ged ${ }^{2,3}$, Yue Lu ${ }^{4,5^{*}}$, Christine Mengin ${ }^{6}$ and Émilie Rousseau ${ }^{2}$
}

\begin{abstract}
This article examines what is being promoted about Tianjin's rich heritage through its tourism and heritage practices. An industrial city traditionally known for its crafts and gastronomy, Tianjin has gradually begun to promote its Chinese heritage and, since the 2000s, its city centre, which is noteworthy for its former foreign concessions and 19th- and 20th-century architectural heritage. After long neglect, the city centre has become a major component in the promotion of the city. Based on the analysis of tourism materials and studies conducted since the mid-2000s, this article first discusses the development of tourism in Tianjin and the chronology and interweaving of the services involved in heritage development. Then, it focuses on the reception of the city's tourism offerings and on urban development operations in two sectors, Wudadao (or 'Five avenues'), located in the former British Concession, and the 'I-Style Town' in the former Italian Concession.
\end{abstract}

Keywords: Tianjin, Foreign concessions, Tourism, Built heritage, Heritage policies, Wudadao, I-style town

\section{Introduction}

The purpose of this collective article is to present a series of reflections on the development of tourism based on Tianjin's architectural heritage as part of the 'Patrimondialisation' ${ }^{1}$ research project conducted at the University of Paris 1 Panthéon-Sorbonne, with various French and foreign institutions. ${ }^{2}$ The case studies are Tianjin, Marrakesh, Old Quebec, Angkor, and the tango (intangible heritage), the last four of which are classified on the World Heritage List. Our common hypothesis is that tourism policies have had a decisive impact on the invention and enhancement of heritage. Is this hypothesis relevant to Tianjin? It does not have any independent sites on the World Heritage List but has two sections of serial World Heritage sites: a pass in the

\footnotetext{
* Correspondence: luyue_2009@hotmail.com

Bruno Chauffert-Yvart, Françoise Ged, Yue Lu, Christine Mengin and Émilie Rousseau contributed equally to this work and should be considered as joint first authors.

${ }^{4}$ International Research Center for Architectural Heritage Conservation, Shanghai Jiao Tong University, Shanghai, China

${ }^{5}$ Equipe Interdisciplinaire de Recherches sur le Tourisme, Université Paris 1 Panthéon-Sorbonne, 21 rue Broca, 75005 Paris, France

Full list of author information is available at the end of the article
}

Great Wall (classified in 1987) and a section of the Grand Canal (classified in 2014).

This article is based on observations collected by heritage professionals and academics during study visits carried out since the mid-2000s and on some 30 interviews conducted in 2016-2018 with many stakeholders, including municipal authorities, writers, academics, and association leaders; it is also based on the analysis of

\footnotetext{
${ }^{1}$ Patrimondialisation is a neologism designating the creation of heritage (patrimoine in French) for tourists in the context of globalisation (mondialisation in French); the project was financed by the French National Research Administration and directed by Maria GravariBarbas. Our warm thanks also go to Delphine Spicq, who took the time to attentively read the first version of this article and to Léa Cléret and Tiffanie Le Dantec for the final text review. We thank David Mulrooney, Ph.D., from Liwen Bianji, Edanz Editing China (www. liwenbianji.cn/ac), for editing the English text of a draft of this manuscript.

${ }^{2}$ The project, funded by the French 'Agence Nationale de la Recherche' and coordinated by Prof. Maria Gravari-Barbas, involves: Equipe Interdisciplinaire de Recherche sur le Tourisme (EA EIREST 7337), Observatoire de la Chine Contemporaine (Cité de l'Architecture et du Patrimoine), UMR CItés, TERritoires, Environnement et Sociétés (UMR CITERES 7324), UMR AUSser 3329 Architecture Urbanisme Sociétés: Savoirs Enseignement Recherche. It proposes a critical reexamination of the historical interference between heritage and national construction in favour of globalisation through heritage.
}

SpringerOpen

(c) The Author(s). 2020 Open Access This article is licensed under a Creative Commons Attribution 4.0 International License, which permits use, sharing, adaptation, distribution and reproduction in any medium or format, as long as you give appropriate credit to the original author(s) and the source, provide a link to the Creative Commons licence, and indicate if changes were made. The images or other third party material in this article are included in the article's Creative Commons licence, unless indicated otherwise in a credit line to the material. If material is not included in the article's Creative Commons licence and your intended use is not permitted by statutory regulation or exceeds the permitted use, you will need to obtain permission directly from the copyright holder. To view a copy of this licence, visit http://creativecommons.org/licenses/by/4.0/. 
Western guidebooks and materials for tourists produced by the city ( $\mathrm{Lu}$ and Mengin 2020), as well as on the available literature. It attempts to present the stages, actors, objects, and recipients of this attempt to increase the value of the city's heritage, and to highlight the complexity of the dynamics at work but does not claim to situate them in the national context of Chinese debates and practices. In doing so, it wishes to shed light on a situation that has not been studied very much in the West, while at the same time investigating different dimensions of Tianjin as a city at the crossroads between cultures.

It should be noted at the outset that there is a lack of comprehensive works on the history of Tianjin in Western languages (Mengin 2014), apart from the specific studies of Maurizio Marinelli on the Italian Concession, Pierre Singaravélou on the international government 1900-1902 (Singaravélou 2017), and Delphine Spicq on running water management 1900-1949 (Spicq 2012). The concession period has been the subject of collective research projects in Europe; theses have recently shed light on various historical aspects (Singaravélou and Tertrais 2014). With regard to tourism development, we should also note Daisy Debelle's thesis on the French Concession (Debelle 2015), Yue Lu's thesis on the Italian Concession (Lu 2017), and Jiali Huang's thesis on the industrial heritage (Huang 2019).

The city's architectural and urban heritage is sometimes still perceived by the media and the general public, and also by urban planners and architects, in a murky way, in a city that was a vector of the first modernisation at the beginning of the twentieth century, when nine Western powers settled there along the Hai River. How has the enhancement of an urban fabric that has long been officially presented as the result of a period of humiliation been implemented? Who were the promoters of this attempt to increase its value, according to which methods, following which evolutions? What relationships were built between heritage and tourism promotion, and who are its instigators, according to which chronology? These are the main themes that guided our steps in trying to understand the urban heritage management and protection policies of the city.

\section{Historical background}

The city benefited from the construction of the Grand Canal under the Sui Dynasty (581 AD-618 AD), and from the very prosperous salt trade. At the intersection of the southern canal toward Hangzhou and the northern canal toward Beijing, Tianjin took advantage of a monopoly situation with respect to northern China, and of canal transportation, which contributed to its prosperity (Kwan 2001). The city's development was linked to the Grand Canal, which transported natural resources from the fertile south, the grain of tribute, and troops to the capital. Tianjin, which became a fortified garrison town in the 15th century, played a central role in the defence of the capital as a port of Beijing.

In his article 'The Salt Battle: Economy, Civil Society, and Foreign Powers in Tianjin in 1900', the historian Pierre Singaravélou $(2014,53,59)$ recalls the importance of the salt merchants' role in Tianjin, a subject already highlighted by Kwan (2001). Belonging to the circle of salt merchants meant being closely involved in urban management and providing aid to the most disadvantaged, funding for festivities, and security for the population of the city. Salt merchants financed and ran the militia and fought fires. They subsidised rice distribution, supported philanthropic and educational works, and organised parades. These merchants also guaranteed the payment of the tax on salt, one of the principal tax resources of the Qing Dynasty (1644-1911). They had the monopoly on salt transport and sales in exchange for the payment of this tax to the government and, consequently, had a close relationship with the city's bankers. In the mid-19th century, the development of maritime transport and the opening of the Tianjin-Pukou and Beijing-Hankou railways greatly reduced the role of the canals as major transport arteries in China.

This quick historical overview recalls that before the Western concessions existed, Tianjin already had a rich history, which was connected to the salt marshes, salt trade, and its strategic positioning on the Grand Canal. The city was managed in an unusual way by a network of merchants and bankers, whom Westerners harshly confronted in 1900, trying to appropriate the salt mounds. This local history has been obliterated for a long time, and only appears now and then in the promotion of the city and in newly built museums, ${ }^{3}$ often limited to old photographs and texts. None of the guidebooks mentioned below or easily accessible websites deals with this phase, which is important in Tianjin's history, as it can open new paths to understanding the urban fabric and making of the city in the late 19th and early 20th centuries. Tianjin's opening to foreign trade after the Opium Wars marked the beginning of another history. From 1860 to 1945, nine concessions were granted to Western nations, who proceeded to build housing, banks, hospitals, factories, cultural, religious, and educational buildings, and other necessities and features of a modern metropolis (Fig. 1). The city became a laboratory for modernisation, largely due to the Chinese elites. From 1937 to 1945, Japanese wartime occupation intensified the development of industry in Tianjin, and the concessions were retroceded. After 1949, when the People's Republic of China (PRC) was established, the city expanded with new housing projects,

\footnotetext{
${ }^{3}$ Visits to the History Museum and the Fort Dagu Museum, July 2017.
} 


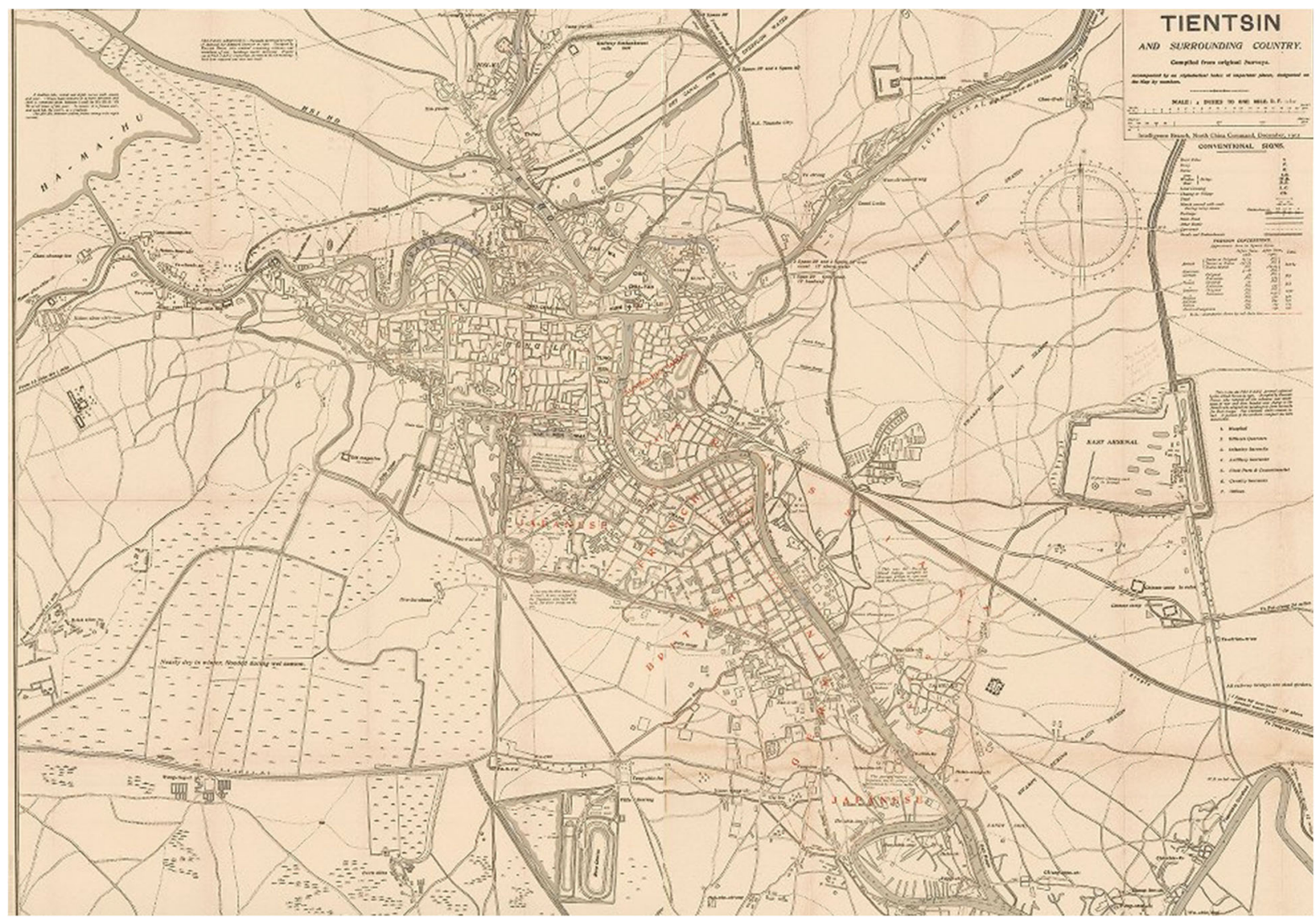

Fig. 1 Map of Tianjin and surroundings, 1903 (Source: https://www.lib.uchicago.edu/e/collections/maps/asian-cities/G7824-T5-1903-G7-W.html)

industrial areas, and cultural facilities. The spatial organisation and the architecture of the city centre along the Hai River are linked to the presence of French, British, German, Belgian, Russian, Italian, Austrian, and Japanese concessions. The buildings of the former concessions were deprecated in the 1980s-1990s as representative of the 'century of humiliation', but are now viewed as remarkable ensembles to be seen in Tianjin.

The municipality of Tianjin, like Beijing, Shanghai, and Chongqing, is directly under the control of the Chinese central government. It has a population of 14 million, who are mostly urban residents. ${ }^{4}$ The population has increased very rapidly, growing from four million in 1964 to seven million in $1986 .{ }^{5}$ More than Beijing and Shanghai, the structure of the municipality was deeply

\footnotetext{
${ }^{4}$ http://worldpopulationreview.com/world-cities/tianjin-population/ showed a figure of 13.9 million (consulted on December 5, 2019) and https://cn.ambafrance.org/IMG/pdf/2014_tianjin_vdef.pdf showed that the population was around 14.1 million inhabitants in 2012 (consulted on December 5, 2019).

${ }^{5}$ The Guide M.A. Chine recalls that in the early 1980s, the city's boom was linked to it being a location for the textile, food, and metallurgical industries, and to the salt marshes and coal and oil reserves (p. 672), to which aeronautics and IT have since been added (Guide M.A. 1987).
}

transformed by the creation of new towns like Wuqing on the expressway linking Beijing to Tianjin, or the new zone of Binhai, sadly known for the explosion caused by dangerous chemical products in 2015. Part of a major economic and industrial centre linking Beijing, Tianjin, and the neighbouring Hebei Province, it offers a contrasting urban landscape.

\section{The rise of tourism}

After the historical context, our paper must focus on the development of tourism in Tianjin. The national guidelines have powerful leverage and help situate the role of local authorities in the development of the built heritage and urban fabric. The China International Travel Service (CITS), established in the early 1950s, has been promoting Tianjin's industrial and commercial function since the 1970s (CITS 1974). The city has benefited from major investments in terms of infrastructure and facilities, including the development of an artificial port in Tanggu, the construction of a dam regulating the Hai River, and the creation of the Water Park (Shuishang) in 1951 in the south of the city. The city is also famous for its crafts and factories: humorous clay characters, New 
Year's prints produced in Yangliuqing, famous wool products, and silk carpets.

The economic reforms launched by Deng Xiaoping in 1978-79 generated interest in Chinese culture and landscapes by encouraging travel within the country. In Tianjin, Li Ruihuan, who was the Communist Party Secretary of the city (1982-1984) and then its mayor (1987-1989), was in charge of the reconstruction of the city which was severely affected by the 1976 earthquake. He led the economic development of what was then one of the first coastal cities to open to foreign investment: he improved transport, water, and gas distribution, and infrastructure according to a policy called 'enlightened conservatism' (Hendrischke 1999, 194). Alongside facilities such as department stores, railway stations, and hotels, a new interest emerged in ancient sites such as Mount Panshan, the Eastern Tombs of the Qing Dynasty, the Dabei Temple (the oldest Buddhist monastery in the city), the Great Mosque, and the Great Wall Pass at Huangyaguan. Tourist maps also suggested a visit to the Zhou Enlai Memorial, the Natural History Museum, the Tianjin Museum of Art, and the Opera Museum in the former Guangdong Guild Hall. To meet the development of domestic tourism, the government built up the city's gastronomy (Nanshi Food Street) and hotels.

The 8th Five-Year Plan (1991-1995) identified tourism as a strategic sector of economic modernisation and as an experimental field to attract foreign investment (Bouteloup 2011, 56). Gradually, to facilitate the transition to a market economy, international tourism offices became responsible for their profits and losses (Ghimire and $\mathrm{Li}$ 2001). These measures had the effect of significantly accelerating the development of the tourism industry, while Chinese domestic tourism was boosted by measures on the extension of holidays: the reduction of weekly working hours from 44 to $40 \mathrm{~h}$ in 1995 , the creation of work-free weekends in 1997, and the introduction of paid holidays in 1999. Thus, in the 1980s, the most visited cities were Beijing, Shanghai, Xi'an, Guilin, Guangzhou, and Hong Kong, but the list grew in the 1990s to include Tianjin (Bouteloup 2011). In 1995, the liveliness of folk traditions, puppets, and stilts in the streets can be seen in photographs from that era, as well as the neoclassical architecture of the former banks, an indicator of the city's wealth at the start of the twentieth century. They were next to ordinary residential neighbourhoods with groups of houses in a courtyard like the hutong in Beijing and the lane houses, such as the lilong or longtang in Shanghai.

In 1998, the Central Committee of the Communist Party decreed that tourism should play a leading role in economic growth, and most local authorities made it a pillar of local development (Zhang 2003, 25). The creation in 1999 of national tourism labels, ranging from the highest $5 \mathrm{~A}$ to the lowest $1 \mathrm{~A}$, strengthened the position of the tourism administration. Tianjin, linked to Beijing by a new motorway, the 'Golden Tourist Corridor', then had the form of a body, the urban agglomeration, and two wings: the Tanggu District, i.e., the port, in the east, and the Ji Country, where Mount Pan is located, in the north (Fig. 2).

The suggested itinerary for a day in the city centre included the Ancient Culture Street, Nanshi Food Street, the Opera Museum (the former Guangdong Guild Hall), and the Water Park. New attractions then emerged, such as the $415 \mathrm{~m}$ high television and radio tower, inaugurated in 1991 and crowned by a revolving restaurant, which was the city's pride and joy at the time. In 1997, the vast Beiping-Tianjin Battle Memorial was built to commemorate the People's Liberation Army's 1949 victory over the Guomindang. The following year, a museum was dedicated to the life and work of Zhou Enlai and his wife, Deng Yingchao. In 1999, a tourist plan published by the city presented Tianjin as a city with more than 600 years of history, 'with a particular aspect, characterised by the mixture of ancient and modern, Chinese and Western architecture'. The architectural modernity highlighted was essentially that of recent buildings. This was also the first mention of the existence of former concessions: 'In the city centre, formerly the concession area of nine foreign countries, there are many buildings in the Western style that have earned the city a reputation as a "Museum of Architecture".' In the early 2000s, the "Hai River Waterfront Comprehensive Development and Transformation Project' was launched, with the construction of vast arteries, bridges, and the specialisation of four areas with differentiated functions; tourism and recreation were focused on historic districts, which by then were profoundly transformed. In 2002, one of the authors of this article visited the oldest part of Tianjin again to find that the part commonly known as the ancient Chinese city within the rectangular hold of the ancient walls (demolished in 1900), so well shown in the maps of local annals, had completely disappeared from the urban landscape (Fig. 3). The desire for modernisation and modernity had taken hold in all the cities of China, where the authoritarian pre-emption of land by local authorities was commonplace, despite protests by residents.

A turning point occurred in 2003 with the appointment of Dai Xianglong, the former governor of the Bank of China, who had an ambitious program for the city as mayor of Tianjin. He wanted to create a new city near the sea and make Tianjin an international port city. On the economic level, with its financial network and the support of Prime Minister Wen Jiabao, a native of Tianjin, Dai attracted both state financing and foreign investment with 
the objective of making the Binhai economic zone as efficient as Pudong in Shanghai or Shenzhen in the south of the country. In a few years, the city had undergone a major transformation, with the construction of a highspeed rail line shortening the journey between Beijing and Tianjin to $30 \mathrm{~min}$, not to mention a regular flow of trains between the two cities, a metro network, road infrastructure, and residential and office towers. Tourism was also one of the objectives, and in 2007 Tianjin aimed to attract one million international tourists and 70 million domestic tourists. Seeing the potential of the heritage of the concession era with new eyes, Dai broke with the theme of foreign humiliation (Becker 2011) and sought the collaboration of European architects and urban planners. As a result, the celebration in 2004 of the 600th anniversary of the city's foundation gave rise to a new narrative of a modern Tianjin, a place of fusion between Chinese and Western civilisation, integrating the concessionary heritage (Marinelli 2010). In the Tianjin Tourism Guide published on this occasion, the 'famous streets' section mentioned two Chinese arteries: the Drum Tower Street in the old Chinese city and the Ancient Culture Street, as well as three Western streets: Heping Road, a commercial street called 'Golden street'; Jiefangbei Road, with its concentration of bank offices, called 'Finance street', and the third, which is a residential district crossed by five landscaped streets, Wudadao (Liu and Chen 2004).

The mayor's strategy was endorsed in 2006 by the State Council's decision to promote Tianjin as an economic centre in North China, which accelerated urban renewal and tourism development, particularly in the Heping District, which became a centre of education, commerce, residence, and cultural life in Tianjin. The district was composed of the central business district, entertainment venues, and all kinds of shopping malls, making it the most cosmopolitan district of Tianjin (Leng and Chen 2017). Since tourism became an integral part of the way of life of the Chinese elite and middle classes, the State Council, through its opinion 'on accelerating the development of tourism in China', established tourism as a pillar of the economy and national service industry for the Chinese population in 2009. During this period, domestic tourism experienced spectacular growth.

In 2013, the State Council published The Outline for National Tourism and Leisure (2013-2020), which launched a new approach to the development and management of tourism in the country (General Office of the State Council 2013). To meet people's growing needs in tourism and leisure, it gave Chinese workers more freedom and flexibility in choosing destinations and travel dates. The State Council of China presented a roadmap for restructuring the then-current paid leave system across China to promote the healthy development of the tourism and leisure industry and build a Chinese-style national tourism and leisure system. These guidelines promoted free access for the public to museums, memorial halls, and sites for patriotic education, and intensified the construction of city parks, leisure streets and areas, recreation belts around metropolises, and distinctive tourism villages and towns to increase the leisure space for residents. The Hai River, enhanced by the development of its banks, cruises, and night lighting, presented a history marked by modernity and the image of an urban and trendy way of life (Fig. 4). The Heping District was the heart of tourism and a showcase of modern history and culture. Binhai, a new urban centre near the sea, was ideal for water-related leisure activities, including the theme park built around the aircraft carrier Kiev. As for the mountainous and natural district of the Ji Country, it hosted green leisure activities.

In 2015, Tianjin was the seventh most visited city in the country, with 170 million Chinese tourists (up from 50 million in 2005) and 3 million international tourists (40\% Japanese and about 20\% Korean, Carter 2017). The main attractions were the less expensive hotel price and the lower cost of fish and seafood: tourists regularly came to Tianjin to dine less expensively than in the capital. As a port, it attracted Korean and Japanese tourists who arrived on cruise ships. The topics of the visits varied according to the travellers' origins. ${ }^{6}$ The aircraft carrier and the History Museum of the Dagu Forts-in a contemporary building designed by the architect Kai Cui-are prized by Chinese tourists, who are attracted by the history of the 19th century, but Western visitors are also expected, as shown by the presence of captions in both Chinese and English.

Tianjin now likes to distinguish itself from Beijing, even though it stands at the capital's outskirts, only 30 min away by high-speed train departing every half hour. Tianjin is, however, $120 \mathrm{~km}$ from Beijing, and the same train trip took two hours in the 1980s. Its proximity to the capital enables it to draw a large number of visitors. It is above all the industrial role of the city and the importance of its international port that have been highlighted, supported by the tourist attractions, such as shopping streets and department stores, and more traditionally gastronomy and crafts. To these features are now added architectural and urban references, linked to the city's history, all of which contribute to giving Tianjin the image of a city where life is good, with a less hectic pace than Beijing (Fig. 5).

\section{Chronology of the protection of heritage in Tianjin}

At the national level, in 1982, the Ministry of Construction defined the national label 'famous historical and cultural city', which required the definition of a protection plan for the old city centre within the master plan

${ }^{6}$ Interview with an official from the Tourist Office in July 2017 with Françoise Ged, Yue Lu, Christine Mengin, and Emilie Rousseau. 


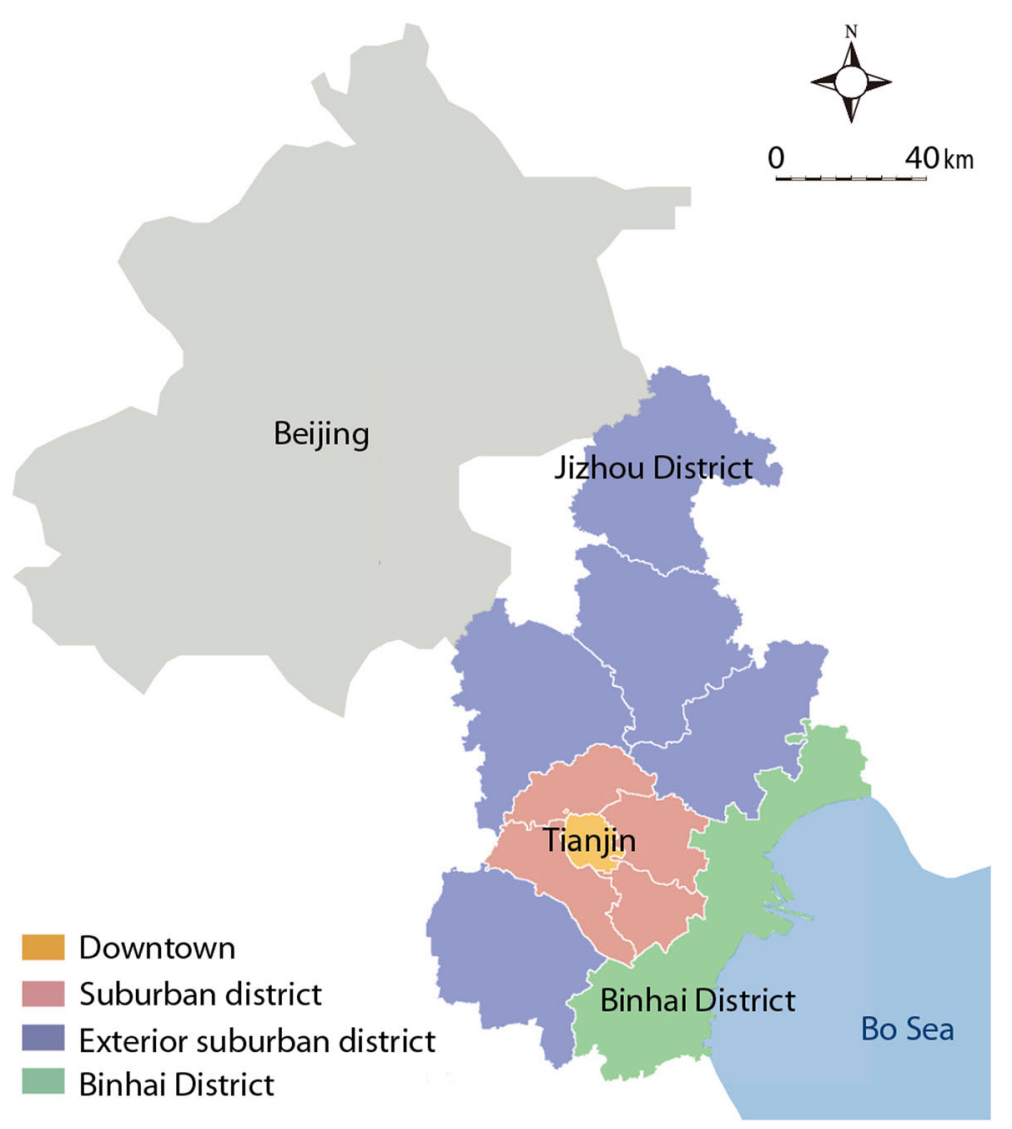

Fig. 2 Map of Tianjin and Beijing (Source: Yue Lu, 2020)

validated by the State Council. ${ }^{7}$ In Tianjin, local authorities have also played an essential role in the development of the built heritage. In 1983, when Tianjin was designated as one of the first coastal cities open to foreign investment, Li Ruihuan, who was then the Party Secretary of the city, discovered Western architecture during a trip to Europe. Back to China, he decided to restore the buildings of the former concessions. At his instigation, a protection zone was defined in the former British Concession (Zhang and Han 2014). In 1987, Tianjin obtained the 'National Famous Historical and Cultural City' label. At the same time, during the 1980s, an inventory of remarkable modern buildings was conducted by Japanese academics in association with Chinese professors, leading to the first publications on the subject in Tianjin and in some 15 Chinese cities (Zhou et al. 1989).

\footnotetext{
${ }^{7}$ In 2008, the Ministry of Construction became the Ministry of Housing, Urban-Rural Development (MOHURD). At the end of 2016, MOHURD accredited 131 historical and cultural cities, which are classified into seven categories. At the end of 2018, urban planning function (and therefore the protection of old districts), which was under the supervision of MOHURD, was placed under the supervision of the Ministry of Natural Resources.
}

In 2005, the 'heritage promotion' process accelerated, and between 2005 and 2013, Tianjin published six lists containing a total of 877 historic buildings, extending over 1.2 million $\mathrm{m}^{2}$ and were divided into three levels of protection: 69 buildings listed as being under special protection (teshu baohu), 205 under major protection (zhongdian baohu), and 603 under general protection (yiban baohu) in the 15 urban and rural districts of the municipality (THBPC 2013). The evaluation criteria are based on 'the unique and authentic character' of the buildings, but this listing does not cite any particular characteristics, unlike the historic monument label in France. In 2006, the State Council of the PRC approved the Tianjin master plan in which nine protected 'historical and cultural areas' (lishi wenhua baohu qu) of $3.57 \mathrm{~km}^{2}$ and five protected 'cultural and historical ambience areas' ${ }^{\text {' }}$

\footnotetext{
${ }^{8}$ Yigong Park; Guyi Street; Chifeng Street; Central Garden; Quanye Store; Chengde Street; Liberation-North Street; Wudadao (Five Avenues); Anshan Street.

${ }^{9}$ The old city; Ancient Culture Street; the Hai River; Liberation-South Street; Tai'an Street. The appellation fengmao (literally means aspect and face) refers to a general ambience and to a number of sites that are classified as less important in the perimeter considered.
} 

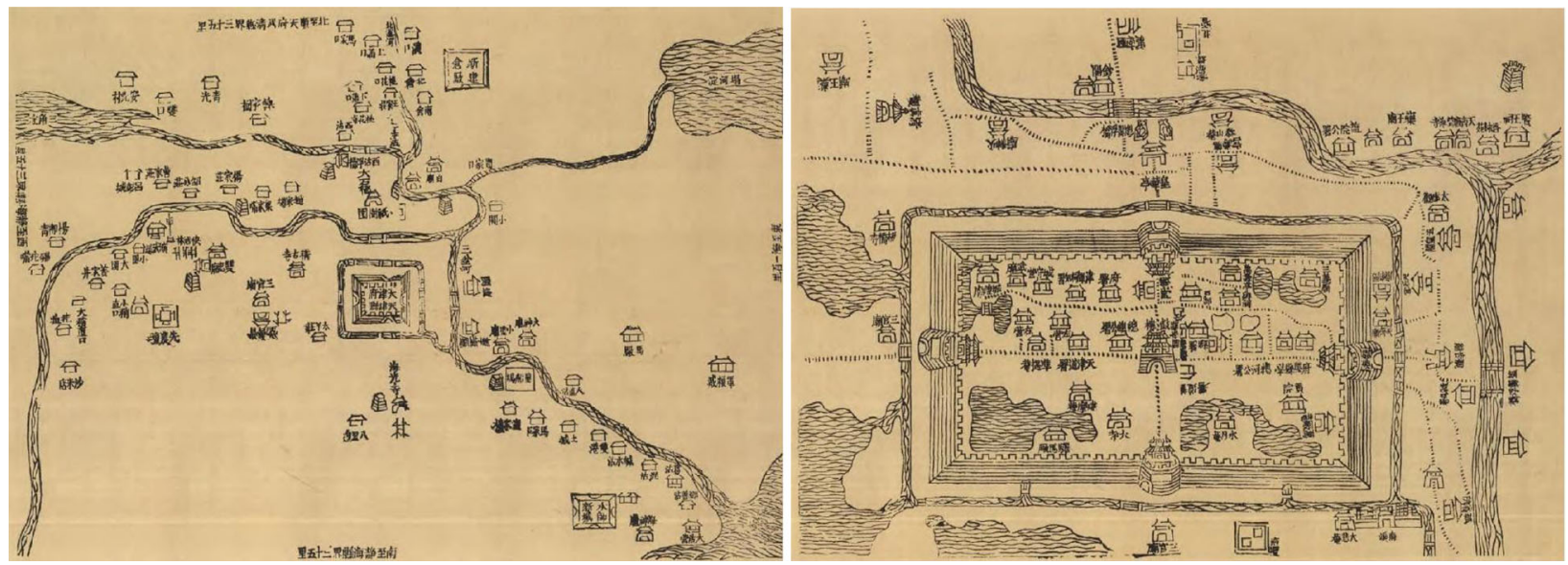

Fig. 3 Map of Tianjin with the city walls (Source: Annals of Tianjin District, 1739)

(lishi wenhua fengmao baohuqu) of $4.95 \mathrm{~km}^{2}$ were defined. In 2011, they were merged into 14 'historical and cultural areas' (lishi wenhua jiequ), and were thus considered to be urban ensembles, as opposed to remarkable isolated entities (Fig. 6).

\section{A superposition of heritage actors in an evolving system}

In fact, contradictory or parallel strategies for heritage protection are emerging, with mixed results (Chauffert-Yvart $2006,2009,2010)$. The display of a heritage protection policy masks the existence of various approaches. They overlap, sometimes conflict, correspond to different practices and influences, and are related to initiatives linked to individuals much more than to a political strategy established at the national level. Tianjin defined its heritage protection system not before the 2000s (Zhang and Han 2014), whereas Shanghai had done so considerably earlier. Its simple inventory had scarcely been followed by any action in the city's offices to label buildings to be protected or to create areas or perimeters to be preserved.

In Tianjin-as in Shanghai, Beijing, and Chongqingunder the authority of their respective ministries, different bureaus are in charge of implementing national regulations and recommendations. There are three distinct offices responsible for the protection of heritage:

1. The Tianjin Municipal Administration of Cultural Heritage under the supervision of the State Administration of Cultural Heritage $(\mathrm{SACH}) .{ }^{10}$ The Tianjin Municipal Administration of Cultural Heritage is in charge of the only 28 cultural relics in the whole municipality, placed under protection on

\footnotetext{
${ }^{10}$ State Administration of Cultural Heritage (SACH or Wenwuju); it defines remarkable properties or real estate on the national level, according to lists that are proposed by the provinces; as of very recently, the buildings listed by the $\mathrm{SACH}$ can have a use other than a museum. The SACH is connected to the Chinese Ministry of Culture.
}

the national level of $\mathrm{SACH}$. But its power is somewhat limited due to the relatively low number of buildings concerned in Tianjin.

2. The Tianjin Planning Bureau is under the supervision of the Ministry of Housing and UrbanRural Development (MOHURD), formerly known as the Ministry of Construction, and now the Ministry of Natural Resources. MOHURD proved to be much more active than the $\mathrm{SACH}$ in developing a heritage policy in cities and provinces, both on the national level and on the local level. It defines the 'historical and cultural' label as applied to towns and villages and, in 2008, the 'Regulations on the Protection of Famous Historical and Cultural Cities, Towns and Villages' were published. They imposed the definition of a larger number of protection plans. In 2011, the Tianjin Planning Bureau defined 14 historical and cultural areas and, in 2015, published the 'Guidelines Relative to the Protection of Historical and Cultural Cities, Towns, and Villages of the Municipality of Tianjin'.

3. The observations of Bruno Chauffert-Yvart during his site visits in Tianjin between 2006 and 2017 show the extent to which the Tianjin Municipal Bureau of Land Resources and Housing Administration (today the Bureau of Planning and Natural Resources), under the supervision of the Ministry of Land Resources and now the Ministry of Natural Resources, has played a central role in heritage management. It created and then managed a heritage label (historic building) for the municipality. Under the supervision of the Ministry of Land and Natural Resources of the PRC, it is in charge of protecting, planning, and managing land, mineral, and marine resources, without having any particular prerogatives with respect to heritage. Created in 2005, the Tianjin Historic Architecture Conservation Committee (Tianjin shi lishi 

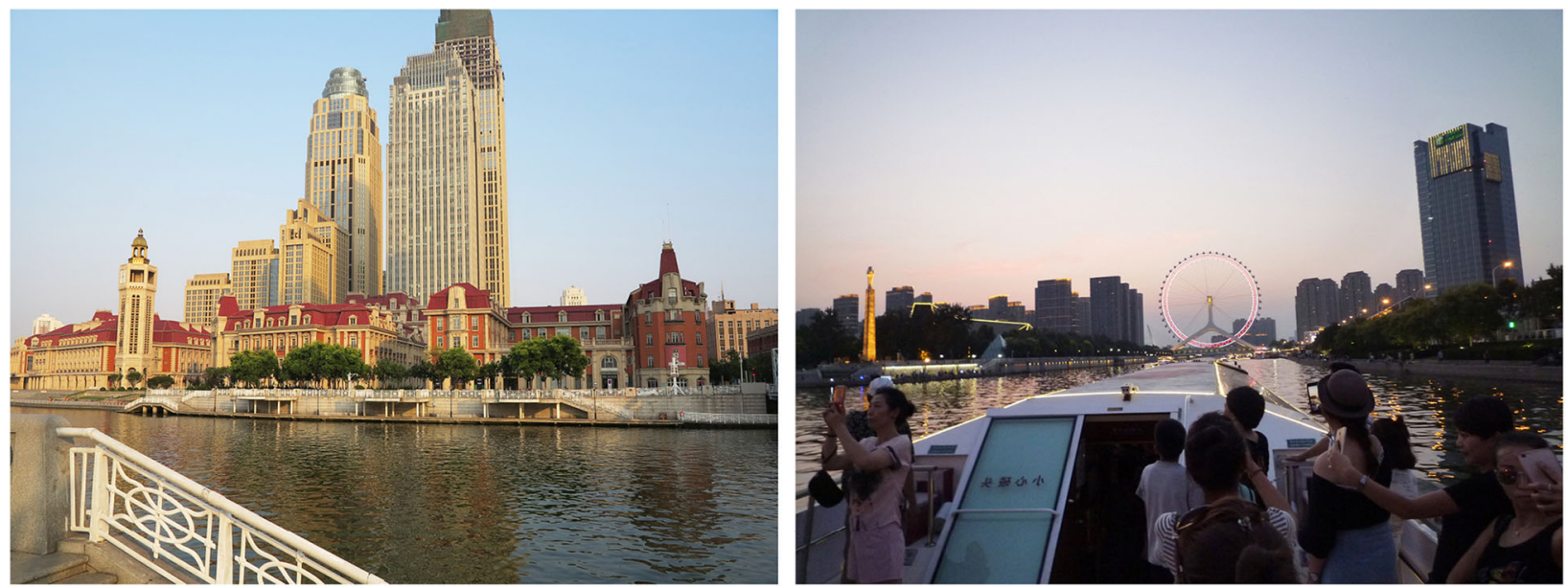

Fig. 4 The banks of the Hai River in Tianjin (Source: Christine Mengin and Emilie Rousseau, 2018)

fengmao jianzhu baohu weiyuan hui) was created under the Tianjin Municipal Bureau of Land Resources and Housing Administration. It plays a key role in applying heritage regulations on the municipality scale. It is composed of experts in urban planning, architecture, cultural heritage, history, society, economics, culture, and the legal sector, and its mission is both to guide the process of rehabilitating or restoring protected elements and controlling the landscape evolutions on sites subject to heritage regulations, notably historic buildings (TBLHA and 20CHC 2016). It controls the application of the 'Regulations on the Protection of Historic Buildings in Tianjin City' (Tianjin shi lishi fengmao jianzhu baohu tiaoli) concerning the listing, restoration, and management of historic buildings (Fig. 7). Two clauses ${ }^{11}$ more specifically define the rules on changing the function of historic buildings and work on the façades. They require the submission of any request to the Tianjin Municipal Bureau of Land Resources and Housing Administration for prior approval before the beginning of any work. The power of the committee is strengthened by the 'Regulations on the Management of Historic Buildings in Tianjin City' (Tianjinshi lishi fengmao jianzhu shiyong guanli banfa) which states: 'Any restoration of a historic building or decoration project must submit a prior declaration for approval to the Tianjin Historic Architecture Conservation Committee Office. ${ }^{12}$ The 'Regulations on the

\footnotetext{
${ }^{11}$ Tianjin municipality, 2005, The 11th Five-year plan Plan of Tianjin, clauses 27-2 and 30 (Municipality of Tianjin 2005).

${ }^{12}$ Tianjin Municipal Bureau of Land Resources and Housing Administration, 2005, article 9; any request requires providing to the Committee a certificate of ownership or a rental lease, an explanatory file accompanied by plans presenting the existing state and the project envisaged, as well as the evaluation report on safety in case of a change in the interior structure.
}

Rehabilitation Techniques of the Historic Buildings of Tianjin" (Tianjinshi lishi fengmao jianzhu baohu xiushan jishu guicheng) and the 'Regulatory Principles for the Protection of the Historic Buildings of Tianjin" (Tianjinshi lishi fengmao jianzhu baohu tuze) established by the Tianjin Municipal Bureau of Land Resources and Housing Administration in 2005 (Lu 2010) were added to them. These regulations and plans provide concrete solutions to problems on the restoration of historic buildings, which must meet modern requirements of structural stability. Article 8, for example, requires any intervention on or restoration of the façade of a historic building be carried out by authorised professionals and that the documents be approved by the structures established by the Tianjin Municipal Bureau of Land Resources and Housing Administration.

The Tianjin Municipal Bureau of Land Resources and Housing Administration, therefore, played a driving role and made the protection and promotion of the urban framework and buildings of the former concessions an important issue. This official initiative, connected to a figure-the deputy director of this bureau-who was very much engaged by the subject, gave the city back a brilliance that has contributed to its appeal for tourists. This policy, however, focused more on places than on inhabitants, who were thrust into the background in this promotion strategy. Providing comfort to the inhabitants and enhancing the urban fabric inherited from the early twentieth century are two distinct aspects that the Tianjin $\mathrm{Mu}$ nicipal Bureau of Land Resources and Housing Administration did not try to combine. The work carried out by the office's director changed the appearance of these areas. The streets became places that invited strolling, with attractive façades and paving - a form of the staging of the city. Its architecture would be the hero, 

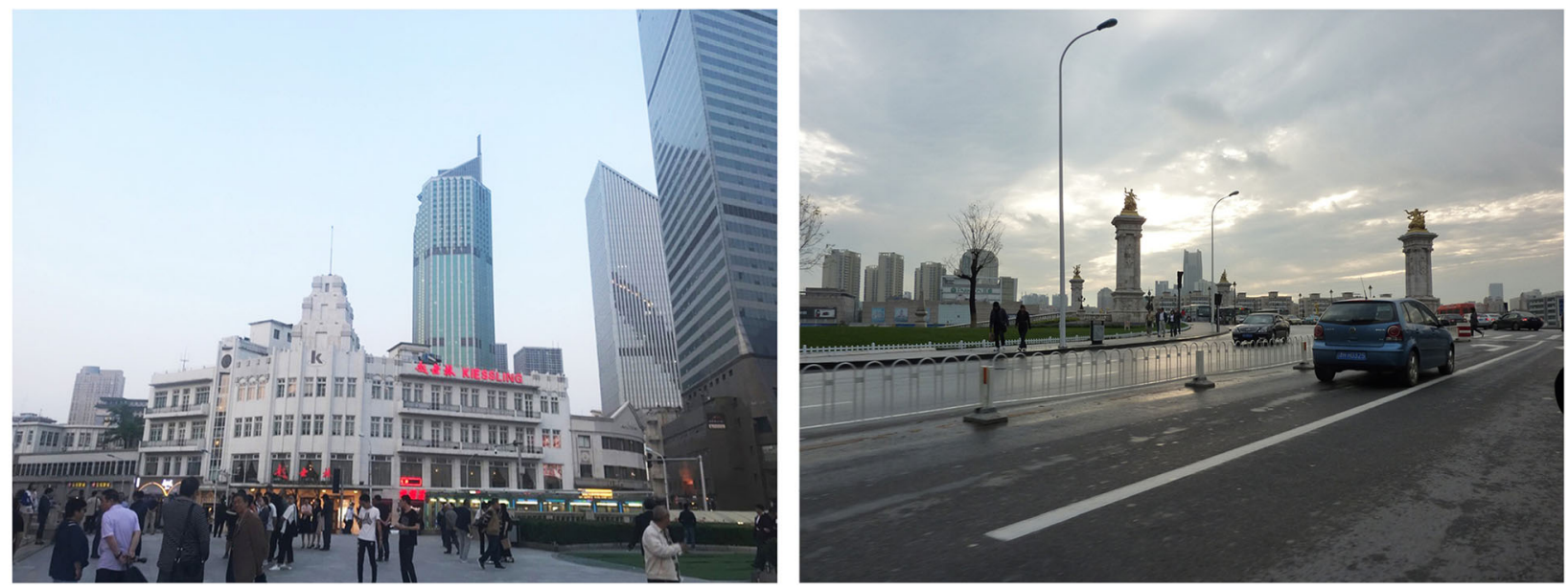

Fig. 5 Left: modern and historic buildings in former foreign concessions in Tianjin (Source: Yue Lu, 2018). Right: a recent 'copy' of the Alexandre III Bridge in Paris (Source: Bruno Chauffert-Yvart, 2018)

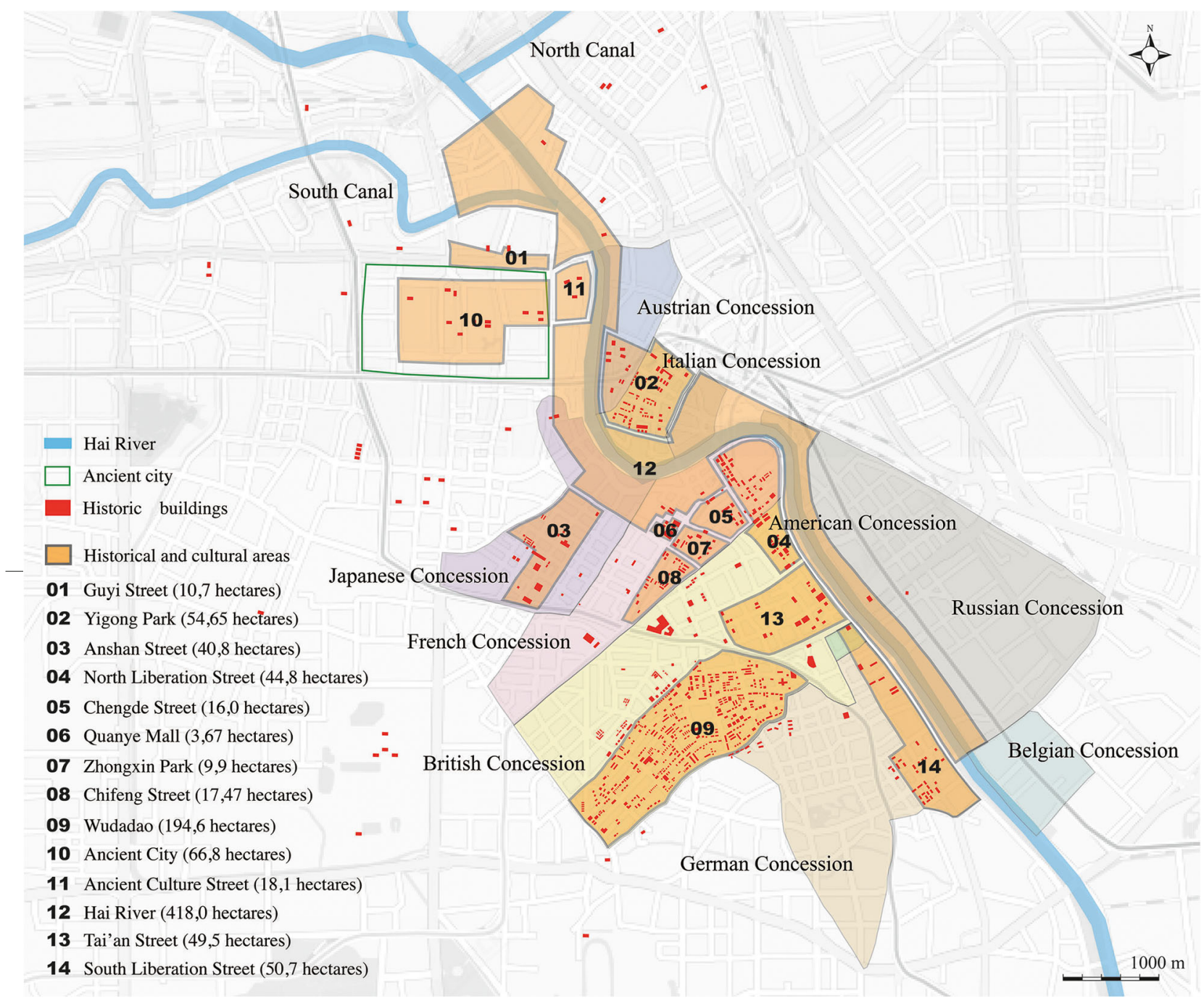

Fig. 6 'Historical and cultural areas' and historic buildings in Tianjin in 2011 (Source: Yue Lu, 2018) 
enhanced by night lighting and the removal of fences between the buildings and the streets.

Having three offices under the supervision of two distinct ministerial authorities did not make shared work on the city and its heritage any easier. Each one set up autonomous rules, selection criteria, and restoration standards, with a limited level of interaction and communication (Li and Zhang 2010). Their implementation was less the result of a strategy than the application, on the local level, of national decisions. Definitions and concepts differed from one department to the other, and the scope of each of the three departments was not clearly established, causing a chaotic superimposition in the administration. The urban cultural heritage plans of the areas reveal that they are more like real estate development plans than urban and heritage management plans (Fig. 8). In fact, the 'protection' plan is a zoning of building opportunities-housing, services and shops-but it is not an urban management plan based on a diagnosis of the built environment and public spaces. It does not seem to be the result of a detailed study of each plot, taking into account its existing state and the project to be carried out, combining protection and development, according to the needs of the inhabitants and the overall urban project.

This chronological essay would not be complete without mentioning the civic and academic contribution to the rise of a sense of heritage. In the 1990s, two projects caused outrage: the demolition of the ancient Chinese city and the destruction-not without opposition-of Guyi Street and its clothes market, which had buildings as old as the Yuan Dynasty (1271-1368).

If the spectacular actions of a famous writer such as Feng Jicai did not save the site, they helped to form public opinion. This was the case with the 'Let's restore our Tianjin' movement, created in 2004 by the Tianjin Volunteer Cultural Heritage Conservation Team, created by retirees, civil servants, students, and journalists on the occasion of the First Cultural Heritage Day in 2006, and the Tianjin Memory Network in 2008. They were all very active in alerting the public to the issues, as well as collecting data on the lived history of Tianjin, and engaging in heritage restitution through exhibitions and publications.

In 2001, Feng Jicai set up the Institute of Arts and Letters within the University of Tianjin, which includes a museum and a research centre on intangible heritage. Another writer, Hang Ying, created a museum of modern history in Tianjin in 2002. Moreover, a great deal of research on the history and architecture of Tianjin is being carried out at the major universities of Tianjin and Nankai, as well as by the Tianjin Federation of Social Science Circle. In view of the publications and their quality, the cause now seems easier to defend. As a result, the Tianjin Museum, inaugurated in 2004 in the so-called Cultural Centre district, is an important part of the city's history. The municipality is also contributing to this effort, and the four volumes on Tianjin's historic architecture published in 2010 are a remarkable testimony to its contribution (Wu 2010).

In addition, regulations on the definition and management of heritage areas are changing rapidly. The lack of connection between the enhancement approach of the Tianjin Municipal Bureau of Land Resources and Housing Administration and the Municipal Tourism Office of Tianjin is very surprising, especially given that Tianjin was the first city in China to establish a tourism university. The destruction carried out by the developers with the support of municipal departments was so intense and property values increased so strongly-the profitability per $\mathrm{m}^{2}$ of a tower is much higher than that of an old building with the same floor area-that opposition arose.

It would rather seem that the promotion of the city's historic urban landscape was developed through contradictory projects, with administrative departments that were formed over the years. Their missions were superimposed or excluded in the compartmentalisation that gradually disappeared. The city's heritage was put forward from the tourism angle, with the creation of joint enterprises that mobilised financing and developed subsidiaries with the objective of stimulating the economy and local tourism. These include the Tianjin Historic Architecture Restoration and Development Co. (THARD) and the Tianjin Haihe Economy Development Office (HEDO), which is responsible for the Hai River sector. These publicprivate partnerships have been a recurring intervention mode in China since the 19th century, during which the system called guandu-shangban, combining public and private management, was created under the Qing Dynasty.

\section{The image of Tianjin in Western guidebooks}

Tianjin's status in tourist guidebooks is uncertain. Some guides, such as Le Routard, which dominates the French market, do not mention it. When selected as a destination, its presentation may vary significantly from one edition to the next. Below is an anthology of extracts from a comprehensive study of guides published in the West since the 1980s. Depending on which travel guidebook and which year one consults, the city is either likeable or not worth the trip. The Lonely Planet ${ }^{13}$ guide dubbed Tianjin the 'Shanghai of the North' in 1988, but only devoted one-third of the pages given over to Shanghai to the city. In spite of

\footnotetext{
${ }^{13}$ The first edition of the Lonely Planet guide to China dates to 1983, shortly after the opening of the country to the West, and it was updated in 1988. It is a guidebook long considered the traveler's reference in a country where access was difficult. Tianjin: pages 532 to 544 and Shanghai pages 322 to 365.
} 

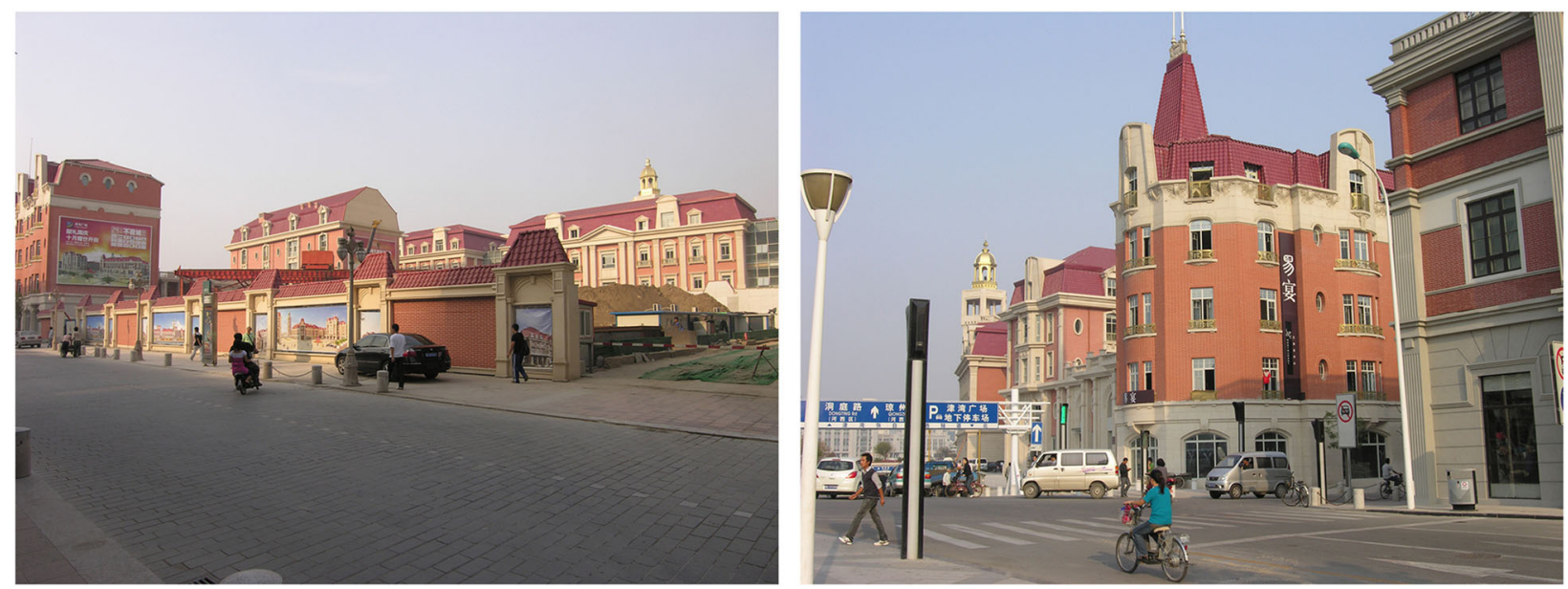

Fig. 7 A 'protected building' (Belfrand) in the former French Concession of Tianjin. Left: the advertisement by the real estate developer on the construction site fence, 2010. Right: the actual building after completion a few years later, 2018 (Source: Bruno Chauffert-Yvart)

this endorsement, the ideal stay suggested was a maximum of only one or two days! A few years earlier, the tour operator Delta, which published a guide in 1980-1981, shortly after China's economic opening in 1978, was scarcely more laudatory. In 'What to see in Tianjin', it says: 'The city doesn't have historic monuments that are remarkable enough to be mentioned here. The interest of a visit to Tianjin resides more in the strolls that can be taken in the central districts and visits to factories and parks.' (Daniele, Giudicelli and Holzman 1980, 179) ${ }^{14}$

The situation reported two years later by Brian Schwartz, who visited the country for six months to do research for his guidebook China off the Beaten Track, ${ }^{15}$ was more encouraging: 'Although much less exciting than Peking or Shanghai, Tianjin is not boring to visit. Many of its streets, like those of any concession city, are an improbable mixture of incompatible architectural styles. Neo-Greek temples stand next to French chateaus decorated with turrets and enormous Art Deco movie theatres crowd Gothic churches, while futuristic glass and steel constructions complete the whole.'(Schwartz 1983).

The 1989 Guide Bleu was barely more generous in its praise for the city's qualities: 'More frequented by businessmen: it does not have any monuments worthy of interest unless we consider as such this mixture of architectures that the presence of several Western powers in this corner of China brought with it. The city can, however, prove to be attractive for those who are

\footnotetext{
${ }^{14}$ Chine $1980 / 81$, p. 179.

${ }^{15}$ China off the Beaten Track; the author informs us at the beginning of the work that he himself visited all the places mentioned during a six-month trip to China, a concern for truth that is rare enough to be pointed out. [Free translation from the French]
}

interested in crafts (many workshops can be visited there).' (Hachette Tourisme 1989, 703) ${ }^{16}$

The 1998 Guide Bleu new edition pragmatically states that: 'Tianjin has trouble attracting tourists: Shanghai, its rival at the bottom of the Yangzi, steals its spotlight [ ... ]' while pointing out that 'modern Tianjin knows how to be warm and remains extremely attached to its old traditions, which show through during its fêtes, in its museums, and in the maintenance of original craft forms'. (Hachette Tourisme 1998, 406) ${ }^{17}$

\section{Today, which attractions for which tourists?}

Although Tianjin was the first Chinese city to create a degree in tourism, ${ }^{18}$ it still seems unequipped to face the new domestic growth driver. Tourism information offices for visitors are practically nonexistent, and websites in Western languages say very little about places to visit. If we look at the tourist sites highlighted by Tianjin, a few characteristics and attractions for tourists in the English language version are presented: 'With striking European-style architecture, many grand buildings and mansions, lively antique markets and ancient temples, it is easy to see why Tianjin has become such an appealing tourist destination. ${ }^{19}$

The following paragraphs describe the remarkable historic sites on the city's outskirts, like the Great Wall, the Dule Temple built over a 1000 years ago, and the museums and conclude: 'Tianjin has become an extremely popular tourist destination and has plenty to keep you occupied during your stay.'

\footnotetext{
${ }^{16}$ Chine, Guide Bleu, p. 703.

${ }^{17}$ Guide Bleu, Chine - de Pékin à Hong Kong, p. 406.

${ }^{18}$ Interview with Mrs. Hong Xu, July 2017 (Christine Mengin, Emilie

Rousseau, Yue Lu, and Françoise Ged)

${ }^{19} \mathrm{http}: / /$ www.world-guides.com/asia/china/tianjin-municipality/tianjin/; consulted on April 10, 2017.
} 


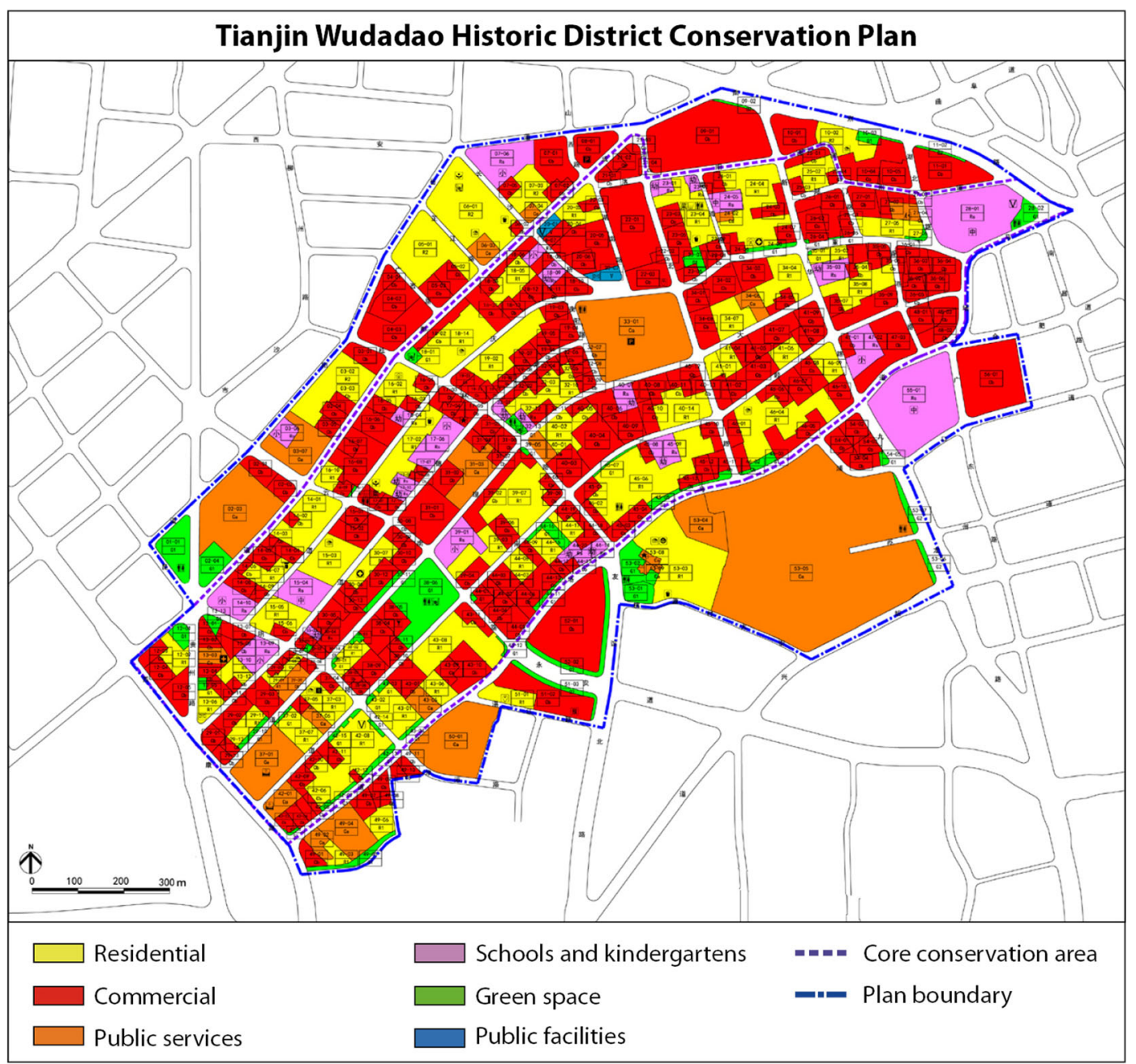

Fig. 8 Conservation plan of Wudadao historic and cultural district (Source: Tianjin municipality, 2011)

If we look at the receiving tourism side and look at the TripAdvisor website ${ }^{20}$ which is one of the first sources consulted by Western visitors, there is no reference to the urban fabric of the former concessions mentioned by the various writers of guidebooks. Referring to a piece of Western architecture as a thematic object of tourism and consumption takes precedence over a vision highlighting ways of living and cultures linked to the history of the places and the personalities who have lived there.

'Within the city of Tianjin, you will find a host of top tourist attractions awaiting. Highlights include the Ancient Culture Street-a group of streets known for their appealing Qing-style architecture-and nearby Tianhou Temple; the lively Antiques Market [...], Dabei Monastery [...] home to a number of impressive Buddhist statues; the eighteenth-century Grand Mosque [...] with

\footnotetext{
${ }^{20}$ https://www.tripadvisor.com/Attractions-g311293-Activities-Tianjin. html "The Top 10 Things to Do," consulted on April 11, 2017.
}

many elaborate carvings; the many Chinese tea houses [...], and the Seaside Amusement Park [...]. If you are looking for an area of green within Tianjin, then visit Beining Park, Central Park, and also the Shuishang Park, which is home to a scenic lake and an amusement area.'

TripAdvisor places the Italian-style Street second of the first 10 things to do in Tianjin, followed by the Wudadao (the Five Avenues) neighbourhood, then by the Ancient Culture Street. The two top attractions are located in the city's former concessions.

The reviews of Tianjin on the TripAdvisor website are mostly written by foreign visitors who may be familiar with Chinese culture, as one of them reveals in a commentary. ${ }^{21}$ These are interesting indicators of the perception of the 'heritage' about which the city now

\footnotetext{
${ }^{21}$ Hua Long Zhu, Western contributor, who mentions a restaurant chosen by his Chinese wife in another comment in April 2017. https:// www.tripadvisor.com/Attraction_Review-g311293-d1814672-ReviewsFive_Great_Avenues-Tianjin.html; consulted on April 11, 2017.
} 
boasts. The messages talk about the ambience, the taste of the dishes, and architecture which is part of the setting in which people appreciate the quality of the sites' restaurants. The tourist seems to be a consumer of food, with the built heritage comprising a 'specific' decor in which to eat and drink: 'The five great avenues or Wudadao are the locations of many historic homes from Tianjin's past. Most are European style with grand architecture and well maintained.'

One of them, staying in Tianjin, is bitter about the Italian-style Street: 'That place just represents everything that is wrong with China. Fake buildings with cheaply made façades for the Chinese tourists from the country. I went to a couple of restaurants around and was highly disappointed by the quality vs. pricing.'

Another Westerner brings up the differences in perception: 'Chinese people love to visit this European-style street in Tianjin, but every time I have been, I have found the food very average and way too pricey. The architecture is quite cool to see though.'

A Serbian visitor from Belgrade is enthusiastic in a quirky way: 'We were spent all day on this touristic attraction in Tianjin, I can say was great experience special for people who was already been in Italia. (sic.)'

The remarks cited show a difference in viewpoints: for the municipality, the main tourist sites are not in the former concessions, whereas the TripAdvisor site highlights visits to the renovated areas of the concessions.

The same discrepancy between the richness of Tianjin's tourist offerings and what Western guidebooks retain about it appears if we compare the sites indicated by two guides published in 2017 (Table 1): the official guide of the City of Tianjin (Tianjin Tourism Bureau 2017) and the Lonely Planet China guide (Harper and Chen 2017, 135-142). The authors have drawn a comparative map (Fig. 9) that shows the tourist attractions appearing in the maps of the Tianjin Tourism Bureau versus those appearing in the Lonely Planet. The spots mentioned in 'Learning Modern China through Tianjin', 'Urban Area Tour', 'Religious Cultural Tour,' and 'Hai River Tour' are indicated in red. The sites recommended by the Lonely Planet are in blue. The sites that appear on both maps are indicated by a black font. This edition of the Lonely Planet guidebook places less emphasis than previous editions on the buildings to be seen in the former concessions. It may be noted that the Tianjin authorities highlight Jinwan Plaza, the rebuilt riverfront, as being impressive at night, while the Lonely Planet mentions 'the treaty port area' with a focus on the former Qing Dynasty Post Office. Only half a dozen sites are in both guides, such as Wudadao, Xikai Church, Porcelain House, and three sites in the old city: the temples of Confucius and Tianhou (the goddess of the sea), and the Ancient Culture Street. The Chinese map boasts 46 sites, compared with the Western map's limited 10-enough for what the Western guide describes as 'an easy one-day trip from the capital, although you may want a long weekend to explore the city properly'.

\section{Two case studies of the former concessions, Wudadao and I-style town}

The old Chinese city, most of which was demolished before 2002, i.e., before the heritage protection plan, has only about 15 listed buildings (1.7\% of the total), and there is virtually nothing left of the lilong and hutong housing landscape, nor of the Hebei New District created by Yuan Shikai in 1903. It is therefore in the former concessions, notably in the British, German, Italian, and French ones, that the most representative groups of the city's heritage are found, classified by category: housing, cultural centres, schools, banks, business centres, offices, churches, leisure centres, sports centres, hospitals, and factories ( $\mathrm{Lu}$ and $\mathrm{Li}$ 2005). Exemplifying the trends described above, the emphasis is given to the Western heritage, which does not represent the complex and rich history of Tianjin: the salt trade and bankers, the Chinese modernisation initiatives and popular traditions, which seem still dissociated from the urban landscape of Tianjin. Narratives about the city, the history of the sites, and the remarkable personalities still appear to be dissociated from the enhancement operations.

Initially absent from materials promoting the city, architecture of Western origin began to be mentioned at the end of the 1990s as part of the government's national labelling policy, before becoming an important element of the municipal narrative in the second half of the 2000s. The spatial organisation and the architecture of the city centre along the Hai River are linked to the presence of the French, British, German, Belgian, Russian, Italian, Austrian, and Japanese concessions in the late 19th and early twentieth century.

We mentioned the change of perspective in the mid2000 s when the 600th anniversary of the city's foundation saw the promotion of Western-style, Europeanstyle, and Foreign-style architecture. On the occasion of the 11th Tianjin Five-Year Plan (2005-2010), the municipality, intending to strengthen this asset, launched a tourism campaign on the theme 'Knowing China's modern history through Tianjin', based on its Sino-Western architectural characteristics, as shown by the subtitle of the Tianjin Official Tourist Map 'Explore Tianjin to find modern China'.

Short films promoting the former French Concession made in 2006 praised the affinities between the banks of the Seine and those of the Hai and the connections between different buildings, Tianjinese and French. Still, 
Table 1 Table comparing the sites appearing on two maps of Tianjin published in 2017 (sites common to both are in boldface)

\begin{tabular}{|c|c|}
\hline $\begin{array}{l}\text { Sites from Tianjin All-in-one Tour- } \\
\text { ism Guide (Tianjin Tourism Bureau } \\
\text { 2017, map) }\end{array}$ & $\begin{array}{l}\text { Sites from Lonely Planet China } \\
\text { Guide (15th edition, 2017, 138) }\end{array}$ \\
\hline \multicolumn{2}{|l|}{$\begin{array}{l}\text { Learning Modern China through } \\
\text { Tianjin }\end{array}$} \\
\hline Five-Avenue Area & Wudadao \\
\hline Garden of Family Zhang & Former residence of Eric Liddell \\
\hline Jing Garden & Minyuan Plaza \\
\hline \multicolumn{2}{|l|}{$\begin{array}{l}\text { Former Residence and Memorial of } \\
\text { Li Shutong }\end{array}$} \\
\hline \multicolumn{2}{|l|}{ Memorial to Boxer Movement } \\
\hline \multicolumn{2}{|l|}{ Site of the Awakening Society } \\
\hline \multicolumn{2}{|l|}{ Old City Proper Museum } \\
\hline \multicolumn{2}{|l|}{ Urban Area Tour } \\
\hline \multicolumn{2}{|l|}{ Five Compounds in Tai'an Road } \\
\hline \multicolumn{2}{|l|}{$\begin{array}{l}\text { Memorial to Zhou Enlai \& Deng } \\
\text { Yingchao }\end{array}$} \\
\hline \multicolumn{2}{|l|}{$\begin{array}{l}\text { Memorial to the Battle of Beiping- } \\
\text { Tianjin }\end{array}$} \\
\hline Confucius Temple Museum & Confucius Temple \\
\hline \multicolumn{2}{|l|}{ Tianjin Radio \& TV Tower } \\
\hline Temple of Sea Goddess & Tianhou Temple \\
\hline \multicolumn{2}{|l|}{ Hai River Tour } \\
\hline Jinwan Plaza & Treaty port area \\
\hline Ancient Cultural Street & Ancient Culture Street \\
\hline Italian-style Town & Former Qing Dynasty Post Office \\
\hline \multicolumn{2}{|l|}{ Yuan Shikai's former residence } \\
\hline \multicolumn{2}{|l|}{ Religious Cultural Tour } \\
\hline Xikai Church & Saint Joseph Cathedral \\
\hline \multicolumn{2}{|c|}{ Seafront Tower (Wanghailou Church) } \\
\hline \multicolumn{2}{|l|}{ Wesley Church } \\
\hline \multicolumn{2}{|l|}{ Dabei Zen Monastery } \\
\hline \multicolumn{2}{|l|}{ Jianfu Kwan-yin Temple } \\
\hline \multicolumn{2}{|l|}{ Guajia Temple } \\
\hline \multicolumn{2}{|l|}{ Others: } \\
\hline \multicolumn{2}{|l|}{ Golden Street (Heping Road) } \\
\hline \multicolumn{2}{|l|}{ Concert Street (Musical Arts Street) } \\
\hline \multicolumn{2}{|l|}{ Dahutong Business Street } \\
\hline \multicolumn{2}{|l|}{ Drum Tower } \\
\hline \multicolumn{2}{|l|}{ Cantonese Guild Hall } \\
\hline \multicolumn{2}{|l|}{ Mosque } \\
\hline \multicolumn{2}{|l|}{ Lingdangge Temple } \\
\hline \multicolumn{2}{|l|}{ Yiku Innovation Industrial Park } \\
\hline \multicolumn{2}{|l|}{ Santiaoshi History Museum } \\
\hline Huayun Museum & \\
\hline Yinluan Monument & \\
\hline
\end{tabular}

Table 1 Table comparing the sites appearing on two maps of Tianjin published in 2017 (sites common to both are in boldface) (Continued)

Sites from Tianjin All-in-one Tour- Sites from Lonely Planet China ism Guide (Tianjin Tourism Bureau Guide (15th edition, 2017, 138) 2017, map)

Former Residence of Duan Qirui

Porcelain House

Palace of Prince Zhuang

Former Residence of Feng

Guozhang

Concert Hall

Nanshi Food Street

Nanshi Hotel Street these houses in the 'Western style' were often characterised by an illustrious figure belonging to the Chinese elite of the first half of the twentieth century, whom they sheltered. Western architecture, therefore, appears to have been legitimised by men who played a role in China's political history, as Tianjin became the preserve of leading actors of the revolutionary era (Tourism Bureau 2017).

Due to historical reasons, most of China's modern built heritage is located in former concessions. Those areas are now downtown urban districts experiencing fast economic growth where there is strong land pressure. Only two areas have been the subject of global development and are resolutely oriented toward tourism: Wudadao and the former Italian Concession, which appeared in 2007 on the city's tourism plan.

\section{The enhancement of Wudadao}

The so-called Wudadao Area corresponds to the Western extension of the British Concession. It is a residential sector built in the 1920s and 1930s and highly prized then by Western and Chinese businessmen and warlords alike. In addition to the five avenues, the district includes 22 streets lined with some 2000 villas with gardens 'built by foreign countries', 300 of which are remarkable for their interior or for the personalities who lived there. After 1949, housing densification was the rule to increase the number of families per villa. Then, following the 1976 earthquake, which caused much devastation, barracks were set up in the courtyards. In 1984, the municipality of Li Ruihuan created an urban planning control office for Wudadao, and in 1986, the State Council approved a master plan stipulating that Wudadao is a conservation area. However, in the absence of a legal framework, high-rise buildings were built on the edge of Wudadao. The municipality promulgated the Planning and Administration Regulations of the Historic 


\author{
Learning Modern China through Tianjin \\ 1. Wudadao (Five-Avenue Area) \\ 2. Garden of Family Zhang \\ 3. Jing Garden (Former Residence of Pu Yi) \\ 4. Former Residence and Memorial of Li Shutong \\ 5. Memorial to Yihetuan Movement (Boxers \\ Memorial) \\ 6. Memorial to the Tianjin Awakening Society \\ 7. Old City Proper Museum
}

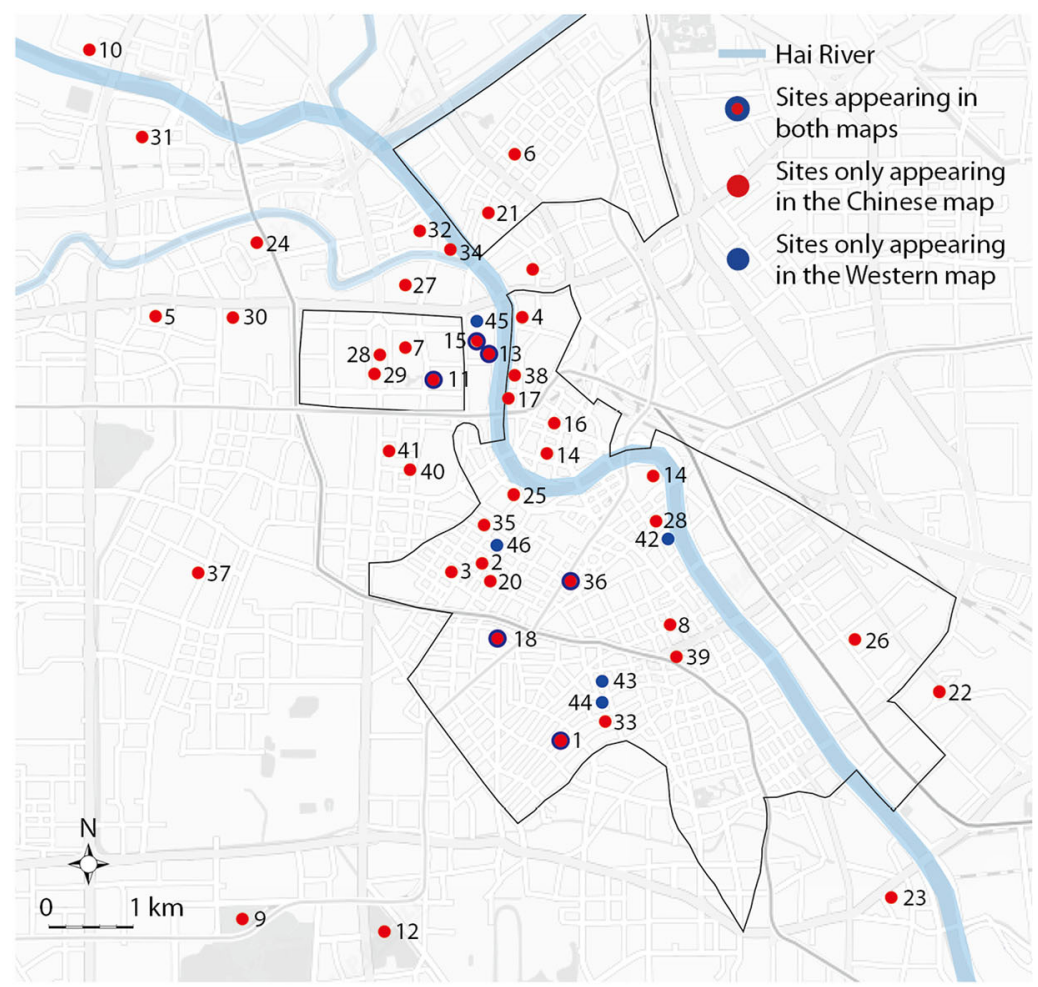

27. Dahutong Business Street

28. Drum Tower

29. Cantonese Guild (Opera Museum)

30. Lingdangge Temple

31. Yiku Innovation Industrial Park

32. Santiaoshi History

33. Huayun Museum

34. Yinluan Monument

35. Former Residence of Duan Qirui

36. Porcelain House (China House)
37. Palace of Prince Zhuang

38. Former Residence of Feng Guozhang

39. Concert Hall

40. Nanshi Food Street

41. Nanshi Hotel Street

42. Qing Dynasty Post Office Museum

43. Former Residence of Eric Liddell

44. Minyuan Plaza

45. Folk Art Museum

46. Shentangdao Antiques Market

26. Tianjin Musical Arts Street (Concert Street)

Fig. 9 Comparative map, illustrating the sites appearing in the map of the Tianjin Tourism Bureau vs. those appearing in the Lonely Planet's map, both published in 2017 (Source: Yue Lu, 2019)

Conservation Areas in Tianjin, registered in the 1999 master plan. To celebrate the 50th anniversary of the $\mathrm{PRC}$, the municipality launched a project to renovate neighbourhoods and historic areas, of which Wudadao was the pilot sector, a project that won a national award in 2004. In 2005, as we have seen, new measures were deployed for heritage protection, and the mayor, Dai Xianglong, pleaded for the protection of 'negative and colonial' heritage (Zhang and Han 2014). An inventory of this heritage was launched, as well as two flagship operations: the rehabilitation of Prince Qing's palace and the creation of urban equipment at the Minyuan Stadium site (Fig. 10).

In the context of the designation of Tianjin as the economic centre of the north and the municipal desire to develop tourism, the Jukemaodi Project (Gathering Tourists in Wudadao) aimed in 2008 to construct a touristic area that included hotels, bars and entertainment facilities, and shopping centres concentrated in a small, specialised area. The implementation of the plan implied the demolition of several old buildings. Within the Wudadao area, 397 buildings were designated as 'historically inflected buildings', but 1036 buildings built before 1949 were not protected by similar regulations.

Against this total restructuring project, the team of volunteers for the 'Protection of Tianjin's Architectural Heritage' warned the authorities, invited experts to inspect the area, and launched a petition. The outcry, widely reported by the media, found an attentive ear even in the government: the Minister of Culture ordered the Jukemaodi Project to stop. In 2010, Wudadao's protection status was upgraded from municipal to national level. The same year, it was chosen as one of the 'China Top 10 Historical and Cultural Streets' from 200 applicants. In 2011, the Five Avenues were identified by the Tianjin Planning Bureau 


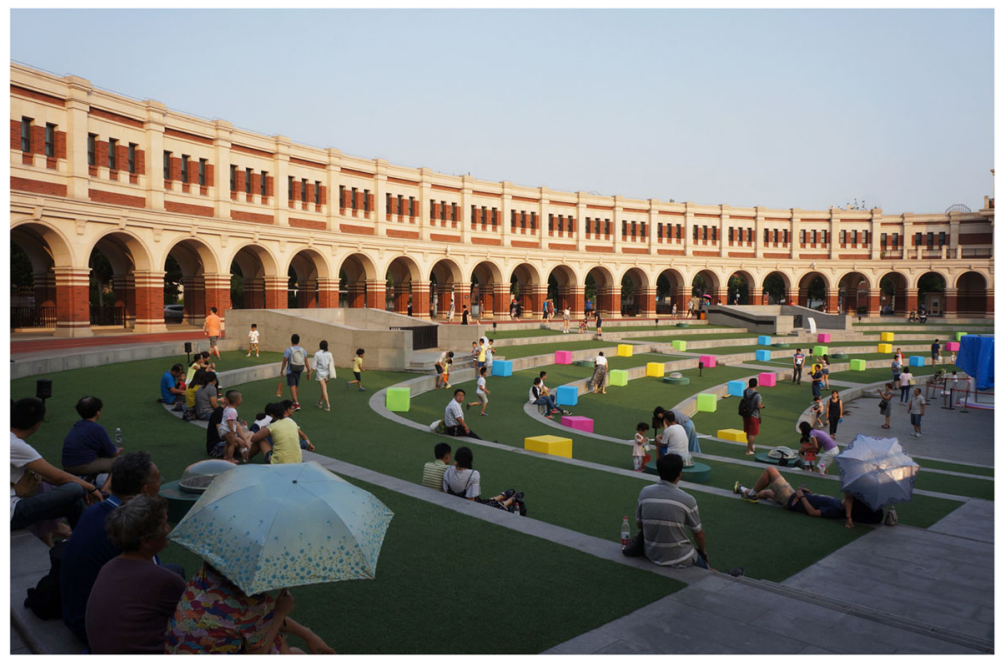

Fig. 10 Minyuan Stadium in Wudadao area (Source: Yue Lu, 2019)

as 'Historical and Cultural Streets.' In 2013, the 'Wudadao Modern Buildings' were designated as 'National Cultural Relics' by the State Council. In 2014, the 'Wudadao Cultural Tourism Areas' received the National Tourism Administration's 4A-level tourist attraction grade. As a consequence, the proportion of tourists in the Five Avenues has increased significantly. According to Wudadao Management Committee, three million tourists visited the area in 2016 (Liu et al. 2019, 234). The enhancement of architectural and urban heritage is now oriented toward the presentation of the houses of important figures in the history of China and the implementation of thematic itineraries, including the Tianjin Museum of Architecture, while experiential tourism is now taken into account. Several small-site museums have opened in recent years. ${ }^{22}$

\section{From the former Italian Concession to the New I-style town}

The valuation of the former Italian Concession was subject to a different dynamic. Built to showcase Italian urban know-how in East Asia, its urban organisation is structured around collective buildings and squares and essentially includes elegant villas. Just like Wudadao, the area had a residential vocation and was highly appreciated by European and Chinese officials, intellectuals, and warlords. From 1949 onwards, the government carried out a series of socialist transformations thereby changing the names of the streets and the functions of the buildings. The Chinese who lived in the Concession in 1947 stayed there until around 1960, but the authorities divided the buildings into one-room apartments and also

\footnotetext{
${ }^{22}$ As revealed by Mr. Wei Er during a meeting at the Tianjin Bureau of Planning and Natural Resources, with Mrs. Hong Lu and her team, 10 May 2019).
}

housed hundreds of families. For 40 years, the places, overcrowded, became impoverished. Then the district went through a phase of destruction, from the Cultural Revolution in 1966 to the Tangshan earthquake in 1976, and many damaged buildings were threatened. A historical sector since 1986, it was one of the 10 projects of the Hai riverbank renovation plan in 2002, with an essentially commercial and tourist vocation. The renovation of the neighbourhood, empty of its inhabitants, began with the demolition of parasitic buildings. The Italian involvement took place within the framework of the strong trade relations between China and Italy: the Lombardy region and the Milan Chamber of Commerce and Industry studied the project as a showcase for Italian industry in the context of the former concession. It coincided bilaterally with a "recupero urbano" project in Italy's year in China in 2006, as a result of which the restoration of the first 20 houses was entrusted to Sirena, a specialised company in Naples. The following 40 houses were taken care of by the Chinese company Flight at a time when regulations were limited to fire safety, hence the replacement of wooden floors with reinforced concrete (Yunfei Li, interview by M. Gravari-Barbas, Sandra Guinand, and Yue Lu, Tianjin, August 18, 2016). Despite the withdrawal of the Italian company, the renovation work in the Italian quarter continued and was finished in 2008. Tianjin's touristic maps indicate the Italian Style Scenic Area (Yishi Fengqingqu), sometimes referred to as the 'Italian Business Park'. In 2009, this area was renamed New I-Style Town (Xinyijie). This renovation was accompanied by several Sino-Italian exhibitions and conferences.

At the end of the 2010s, the 'Italian Style Street' was in a state of near completion. In its time, it had been an innovative area of the former Italian Concession. During a 
visit in December 2010, we could see couples coming to take pictures, braving the rigours of winter in their lightweight wedding outfits. The professors of Tianjin University, our guides, told us that the inhabitants had been rehoused with low indemnities, but this type of project, launched a few years earlier, had now become harder to carry out without the inhabitants' agreement. The analysis of the conditions under which French-Italian cooperation was constituted conducted by Christine Mengin shows that rather than a pilot rehabilitation project of a historic area, the operation was intended to open up markets in China to the know-how of Italian companies (Mengin, 2017). The district has now become a place of leisure, offering Western-style decor for visitors or local residents, who enjoy the open spaces of the terraces, cafés, and restaurants (Lu 2017).

The tourist maps recently published in Tianjin reveal these ambiguities. On one of them, an aerial view like a hand-drawing for children shows the Five Avenues as a somewhat eccentric and charming collection of small houses with red roofs, set alongside small cubic structures, each of them a little lopsided and served by parallel streets. Modernity and mobility go hand in hand: an aeroplane, a high-speed train, a car, a bus, and towers are on the edges of the map. The couple arriving on a tandem bicycle provide an idea of the public targeted, i.e., young people who go to Wudadao for relaxation and leisure (Fig. 11).
The map displayed at the entrance of the Italian Style Street has similar codes. Its English title is 'Tianjin Italian Style Tourist Areas Map' and slightly to the left is 'Italian-style town' with a capital I and N, which may be intended as an encouragement to be 'in' when visitors arrive. On the map, the line is more rigorous; the bird'seye view isolates a neighbourhood delimited by two large tree-lined axes, with the Marco Polo Square and its famous monument opening onto a perpendicular pedestrian street. The buildings are succinctly represented, and they are mostly bars or restaurants, art galleries, and photo shops (studios for wedding pictures) (Fig. 12). Although this Italian Style Street was the object of a partnership with Italian developers and architects to promote the cultural value of this heritage, in the early 2000s, it became a Western decor for leisure for the Tianjinese middle class as well as for tourists. The display of Italianness originally wanted by the Italian authorities who built the Concession, and still conveyed today by the initial urban design and the remaining buildings, is more likely to be perceived by Westerners than by Asian visitors. Some of the streets have been named with new Italian appellations, such as Marco Polo Square, but the Italiantranscultural atmosphere (Marinelli 2019) is diluted by a flavour of Europe in general, materialised by a variety of cafés and restaurants. Fountains, fake golden statues, wood chalets for commerce, and the transformation of the zone in a pedestrian mall are a global phenomenon.

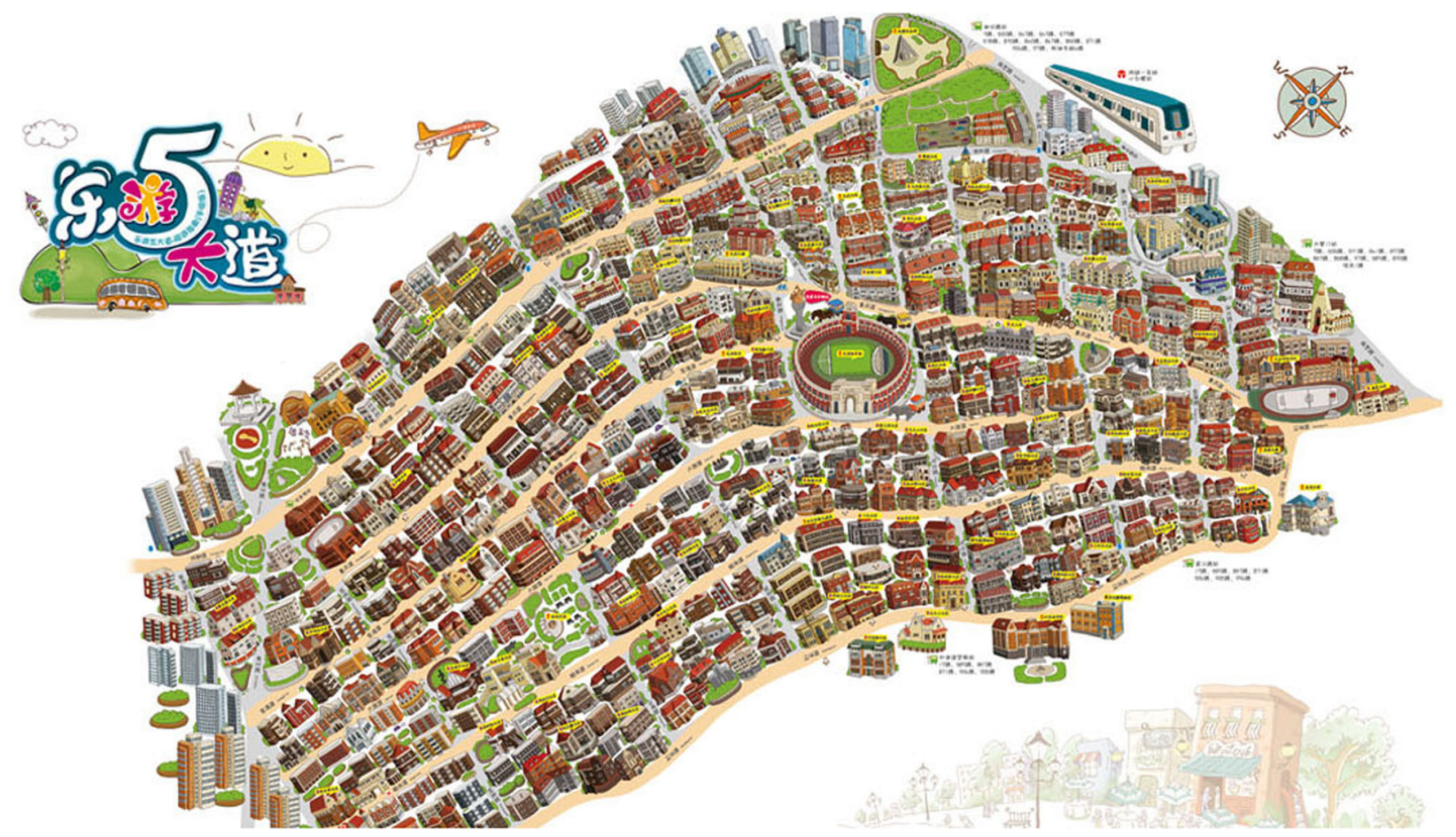

Fig. 11 Tourist map of Wudadao published in Tianjin (Source: Tianjin Tourism Bureau, 2014) 

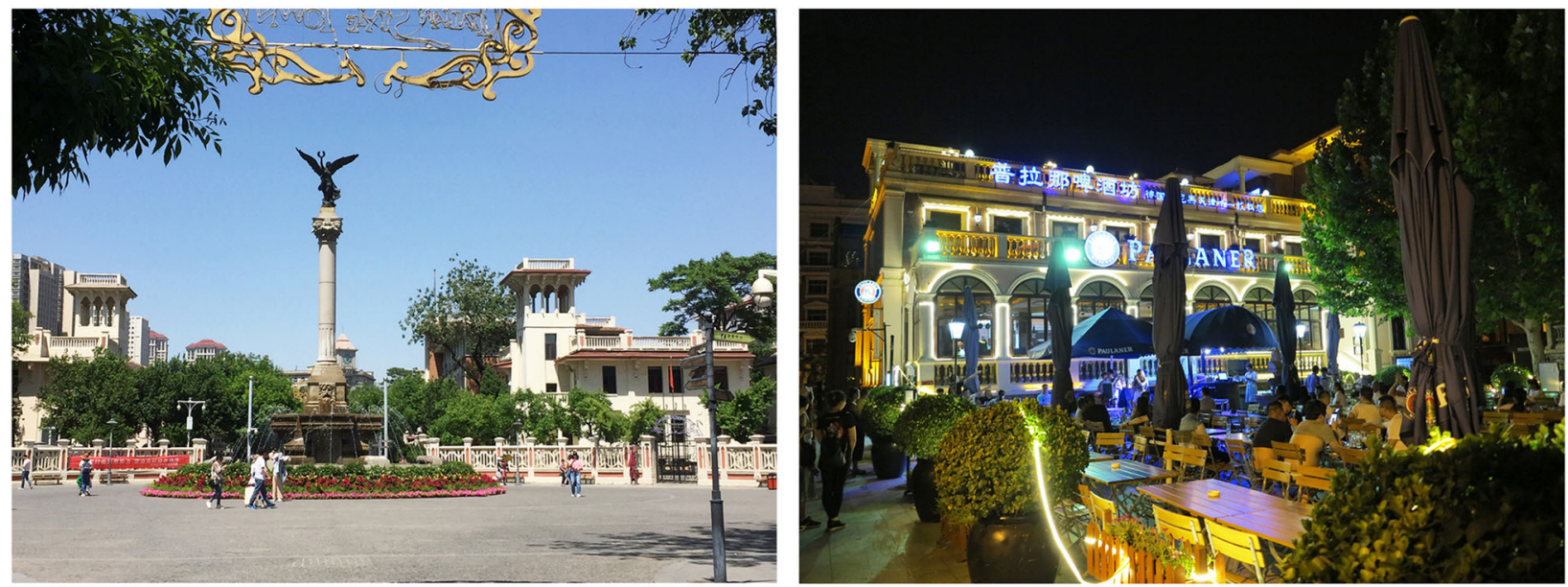

Fig. 12 A villa in Marco Polo Square transformed into a restaurant (Paulaner) in the New I-Style Town in Tianjin (Source: Françoise Ged and Emilie Rousseau, 2018)

The Florentia Village, an outlet mall for top luxury fashion brands built halfway between Beijing and Tianjin, is not an imitation of ancient Italy. When a new building as significant as the Tianjin Planning Exhibition Hall was created, it was not an imitation of an existing monument. The same Milanese architectural firm, Progetto CRM, created an architecture both recalling Italian classicism and adjusted to Tianjin's modern environment. In the Italian Style area, the landmarks for Chinese tourists are to be found in the villas of such famous writers as Liang Qichao or Cao $\mathrm{Yu}$, both of which are open to visitors. The Italian Style town has been an experimental way to deal with the historical substance of the former concessions but is no longer used as a reference.

\section{Conclusion}

Our investigation shows that the interaction between tourism development and heritage conservation in Tianjin has been carried out by various forces over time and that the humiliation of the colonial era has been overcome through consumption and leisure. The Italian Concession has become a place of leisure for urban youth and tourists, especially in groups; Wudadao is also aimed at tourists, but at individuals, who prefer to travel by bicycle, rather than groups and at local residents who appreciate the neighbourhood equipment in the Minyuan Stadium.

Moreover, these two areas are part of the 'urban thematisation' phenomenon, defined as the practice of a city seeking to distinguish itself by focusing on a specific theme (Richards and Wilson 2006). Tianjin claims to be 'a museum of international architecture', telling 'modern Chinese history of one hundred years from another angle' (Travel guide 2018). Wudadao is presented as the 'most attractive scenic area in Tianjin', where 'wandering in the villas arranged in rows feels as though one is going back in time', and where one can 'listen to stories of these Western-style buildings', and 'see the former residence of some important person in the past' (Zhang 2018).

This built heritage is clearly used to define the identity of Tianjin in a globalised world, as well as to enhance its attractiveness. In this respect, the Western historical architecture seems insufficiently eloquent, and it is striking to see how the staging of the arrival in Tianjin from the station transformed a historic building on the other side of the river, the Belfran, into a flamboyant riverfront with motifs inspired by classical and eclectic French architecture. The uses of and references to Western architecture in recent buildings in Tianjin should definitely be further studied.

It is interesting to see that in Tianjin, folk arts, craft, and the ambience of the streets were highlighted in the travel guides mentioned, raising the question of whether this was due to the lack of anything else to recommend to the visitor. These subjects are a cause for one of the city's most famous literary figures, the writer and calligrapher Feng Jicai, who was born there. His battle against urban destruction has been almost in vain (Meyer 2009), ${ }^{23}$ and his position in the Chinese People's Political Consultative Conference (CPPCC) has carried little weight in this battle. He worked to create the Feng Jicai Institute of Literature and Art, Tianjin University, which places an emphasis on intangible heritage. Faced with this evolution, other demands on memory, popular traditions, and intangible heritage are emerging among professors, professionals, and administrators. The role of this famous writer, defender, and promoter of the popular arts undoubtedly has something to do with this perspective. While a folklore museum has existed since

\footnotetext{
${ }^{23}$ See the interview of Feng Jicai with Michael Meyer, who was stunned by the destruction of Beijing before the 2008 Olympic Games, pp. 251-259.
} 
1989, it is noteworthy that an intangible heritage museum has recently opened in Minyuan Plaza.

The knowledge produced by the many Chinese academic studies, and the no less numerous data collected by Tianjin's heritage associations, has a hard time being disseminated and interpreted. In particular, the approach of academics and intellectuals to protecting and rehabilitating the old centre of Tianjin, including the former concessions and the Chinese city, and their analysis of the fusion of Chinese and Western components have remained marginal, not to mention the modernisation of the city by Chinese elites as in the Hebei New District. In this respect, it is noticeable that a new theme is developing, the idea of a mixed heritage because 100 years ago, Chinese people and foreigners existed together and affected each other. If the Italian-style zone is perceived as the most 'intact and distinctive' among the remaining concessions, with admirable architectural design and planning, Wudadao includes not only European-style and Japanese-style buildings, but also some 'fusion-style' ones because the earliest residents were mainly Chinese, and Chinese aesthetic interests were integrated into the Western-style architecture (Zhang 2018). This approach to this heritage and its impact as mixed, intercultural architecture could no doubt be a fruitful path to further research and value enhancement of Tianjin's architectural heritage.

\section{Acknowledgements}

The authors thank Maria Gravari-Barbas and Sandra Guinand for participating in the field trips and for providing copies of scientific articles. We thank the Executive Editor Plácido González Martínez and two anonymous reviewers for their helpful comments.

\section{Authors' contributions}

All authors designed research, acquired data on the field, and analyzed the results. Françoise Ged, Christine Mengin and Yue Lu drafted the manuscript. All authors read and approved the final manuscript.

\section{Funding}

The study was supported financially by the National Agency for Research (ANR; project PATRIMONDI).

\section{Availability of data and materials}

All data generated and analyzed during this study are included in this published article or in the cited references. The studied material is stored in the collections of the Observatoire de l'architecture de la Chine contemporaine in Paris, France.

\section{Ethics approval and consent to participate}

Not applicable.

\section{Consent for publication}

Not applicable.

\section{Competing interests}

The authors declare that they have no competing interests.

\section{Author details}

${ }^{1}$ BCY Consultants, 1, Passage de la Charité, 78000 Versailles, France. ²Observatoire de l'architecture de la Chine contemporaine, Cité de l'architecture et du patrimoine, Palais de Chaillot, 1 place du Trocadéro et du 11 novembre, 75116 Paris, France. ${ }^{3}$ Associate researcher of Centre Chine,
UMR Chine Corée Japon (CNRS-EHESS), Paris, France. ${ }^{4}$ International Research Center for Architectural Heritage Conservation, Shanghai Jiao Tong University, Shanghai, China. ${ }^{5}$ Equipe Interdisciplinaire de Recherches sur le Tourisme, Université Paris 1 Panthéon-Sorbonne, 21 rue Broca, 75005 Paris, France. ${ }^{6}$ Université Paris 1 Panthéon-Sorbonne, INHA, 2 rue Vivienne, 75002 Paris, France.

Received: 13 May 2019 Accepted: 6 April 2020

Published online: 30 June 2020

\section{References}

Becker, Antoaneta. 2011. Tianjin Embraces its Colonial Legacy. Interpress Service http://www.ipsnews.net/2011/08/china-tianjin-embraces-its-colonial-legacy/. Accessed 1 Apr 2020.

Bouteloup, Eric. 2011. Tourisme, patrimoine et disneylisation de la Chine contemporaine : le cas de Lijiang. PhD diss., Université de Lyon.

Carter, Roger. 2017. Case Study of Tianjin. Presentation to the Technical Workshop: "UNWTO - WTCF City Tourism Performance Research".

Chauffert-Yvart, Bruno. 2006. Compte-rendu de mission à Tianjin 18-23 octobre 2006. [Mission report to Tianjin October 18-23, 2006].

Chauffert-Yvart, Bruno. 2009. Compte-rendu de mission en Chine Tianjin 15 au 17 septembre 2009. [Mission report to China Tianjin September 15 to 17, 2009].

Chauffert-Yvart, Bruno. 2010. Compte-rendu de mission en Chine 19 au 28 septembre 2010. [Mission report to China September 19 to 28, 2010].

CITS (China International Travel Service). 1974. Direction générale de l’Agence du tourisme international de Chine. [China International Tourism Agency Branch]. In Guide touristique de Chine [China Travel Guide], 42-47. Beijing: Éditions en langues étrangères.

Daniele, Crisà, René Giudicelli, and Marie Holzman. 1980. Chine. 1980-1981 [China. 1980-1981]. Paris: Édition Centre Delta.

Debelle, Daisy. 2015. Les nouvelles dynamiques du tourisme et de la patrimonialisation en Chine : étude des anciennes concessions et du quartier français de Tianjin en particulier. [The New Dynamics of Tourism and Heritage Development in China: Study of the Old Concessions and The French Quarter of Tianjin in Particular]. PhD diss., Université Paris 1 Panthéon-Sorbonne/Tianjin University.

General Office of the State Council. 2013. Guomin Ivyou xiuxian gangyao (20132020). [The Outline for National Tourism and Leisure (2013-2020)].

Ghimire, Krishna, and Zhou Li. 2001. The Economic Role of National Tourism in China. In The Native Tourist: Mass Tourism within Developing Countries, ed. Krishna Ghimire, 86-108. London: Earthscan.

Guide, M.A. 1987. Chine, les guides M.A. Paris: M.A. Éditions.

Harper, Damian, and Petra Chen. 2017. China. 15th ed. Footscray, Victoria and Oakland: Lonely Planet.

Hendrischke, Hans. 1999. Tianjin-Quiet achiever? In The Political Economy of China's Provinces: Competitive and Comparative Advantage, ed. Hans Hendrischke and Chongyi Feng, 183-210. London: Routledge.

Huang, Jiali. 2019. Le réseau d'électricité de Tianjin (Chine), 1900-1960. Histoire et valorisation patrimoniale. [The Tianjin (China) Electricity Network, 1900-1960. Heritage History and Enhancement]. PhD diss., Université Paris 1 PanthéonSorbonne.

Kwan, Man Bun. 2001. The Salt Merchants of Tianjin: State-Making and Civil Society in Late Imperial China. Honolulu: University of Hawaii Press.

Leng, Tse-Kang, and Rung-Yi Chen. 2017. Local State Adaptation and Grass Roots Participation: Tianjin and Nanjing's Preservation of Cultural Relics in Comparative Aspects. Journal of Contemporary East Asia Studies 6 (2): 187209

Li, Jinli, and Wei Zhang. 2010. Kuaisu fazhan de Tianjin chengshi yu yichan baohu. [The Protection of Heritage in The Rapid Development of the City of Tianjin]. Time+Architecture no. 5: 16-21.

Liu, Fengyin, and Zhongxin Chen, eds. 2004. Tianjin Tourism Guide. Beijing: China Intercontinental Press.

Liu, Tianhang, Richard Butler, and Chunyan Zhang. 2019. Evaluation of Public Perceptions of Authenticity of Urban Heritage Under the Conservation Paradigm of Historic Urban Landscape-A Case Study of the Five Avenues Historic District in Tianjin, China. Journal of Architectural Conservation 25 (3): 228-251.

Lu, Hong. 2010. Tianjin lishi fengmao jianzhu kechixu baohu liyong tansuo. [Studies on the Protection and Durable Promotion in Tianjin]. China Real Estate no. 1: 77-80. 
Lu, Hong, and Ru Li. 2005. Tianjin jindai fengmao jianzhu 1840-1949. [Modern Architectures in Tianjin 1840-1949]. Tianjin Sciences \& Technology no. 1: 19-26.

Lu, Yue. 2017. De l'ancienne concession italienne de Tianjin à I'I-Style Town. Enjeux et processus de la patrimonialisation et du développement touristique. [From The Old Italian Concession in Tianjin to I-Style Town. Issues and Process of Heritage Development and Tourism Development]. PhD diss., Université Paris 1 Panthéon-Sorbonne.

Lu, Yue, and Christine Mengin. 2020. Les concessions occidentales dans la mise en valeur toursitique de Tianjin: un patrimoine ambivalent. [Western Concessions in Tianjin Tourism Development: An Ambivalent Heritage]. In Le patrimoine Mondial, mise en tourisme, mise en images [World Heritage, Tourism, Images], ed. Maria Gravari-Barbas, 147-172. Paris: L'Harmattan.

Marinelli, Maurizio. 2010. The 'New I-Style Town': From Italian Concession to Commercial Attraction. China Heritage Quarterly http://www. chinaheritagequarterly.org. Accessed 1 Apr 2020.

Marinelli, Maurizio. 2019. Domesticating Italy's Foreignness in China: The Transcultural Politics of the Copy and the Real. Modern Italy 24 (4): 417-136.

Mengin, Christine. 2014. Écrire l'histoire des concessions de Tianjin par l'architecture: état des lieux. [Writing the History of the Tianjin Concessions through Architecture: Inventory]. Outre-mers. Revue d'histoire 102 (382-383): 13-25.

Mengin, Christine. 2017. Tianjin : de la concession internationale à l'objet patrimonial mondialisé, au prisme de la coopération sino-italienne, article written for the intermediate presentations of the ANR. unpublished.

Meyer, Michael. 2009. The Last Days of Old Beijing - Life in the Vanishing Backstreets of a City. New York: Walker \& Company.

Municipality of Tianjin. 2005. Tianjin shiyiwu guihua. [Tianjin 11th Five-Year Plan].

Richards, Greg, and Julie Wilson. 2006. Developing Creativity in Tourist Experiences: A Solution to the Serial Reproduction of Culture? Tourism Management 27 (6): 1209-1223.

Schwartz, Brian M., and Bill Newlin. 1983. La Chine hors des sentiers battus [China off the Beaten Track]. Translated by Daniel Glinz. London: Haril Press.

Singaravélou, Pierre. 2014. La bataille du sel. Economie, société civile et puissances étrangères à Tianjin en 1900. [The Battle of Salt. Economy, Civil Society and Foreign Powers in Tianjin In 1900]. In Outre-mers. Revue d'histoire: De Tientsin à Tianjin. Internationalisation et patrimonialisation des concessions (1860-2030), ed. Pierre Singaravélou and Hugues Tertrais, 47-69. Paris: Persee.

Singaravélou, Pierre. 2017. Tianjin Cosmopolis - Une autre histoire de la mondialisation [Tianjin Cosmopolis-Another Story of Globalization]. Paris: Éditions du Seuil.

Singaravélou, Pierre, and Hugues Tertrais. 2014. De Tientsin à Tianjin. Internationalisation et patrimonialisation des concessions (1860-2030). Outremers. Revue d'histoire 102 (382-383): 7-147.

Spicq, Delphine. 2012. L'avènement de l'eau courante à Tianjin, Chine 1900-1949 [The Advent of Running Water in Tianjin, China 1900-1949]. Sarrebruck: Éditions universitaires européennes.

TBLHA (Tianjin Municipal Bureau of Land Resources and Housing Administration), and 20CHC (20th-Century Architectural Heritage Committee of Cultural Relic Society of China). 2016. Wenjin xundao: Tianjin lishi fengmao jianzhu baohu shinian licheng [A Glimpse of Tianjin, An Appreciation of Historic Architecture Protection]. Tianjin: Tianjin University Press.

THBPC (Tianjin Historic Buildings Protection Commission and Tianjin Municipal Bureau of Land Resources and Housing Administration). 2013. Atlas of Historic and Stylistic Architecture in Tianjin. Tianjin: Tianjin University Press.

Tianjin Tourism Bureau. 2017. Welcome to Tianjin, a City of Taste, a City of Joy. Tianjin all-in-one-Tourism Guide.

Tourisme, Hachette, ed. 1989. Chine, Guide Bleu. Paris: Hachette Tourisme.

Tourisme, Hachette, ed. 1998. Guide Bleu, Chine-de Pékin à Hong Kong. Paris: Hachette Tourisme.

Wu, Yanlong, ed. 2010. Historic Architecture in Tianjin. Vol. 4. Tianjin: Tianjin University Press.

Zhang, Guangrui. 2003. China's Tourism since 1978: Policies, Experiences, and Lessons Learned. In Tourism in China: Geographic, Political, and Economic Perspectives, ed. Alan Lew and Lawrence Yu, 3-17. Boulder: Westview Press.

Zhang, Lina, ed. 2018. Tianjin Travel Guide, Compiled by the Tianjin Municipal Tourism Administration. Beijing: Science Press.

Zhang, Tianjie, and Sunsheng Han. 2014. Preservation and Regeneration Strategies for the Wudadao (Five Avenues) Area, Tianjin, China. China City Planning Review 23 (4): 62-72

Zhou, Zushi, Fuhe Zhang, Shin Muramatsu, and Joji Terahara, eds. 1989. Zhongguo jindai jianzhu zonglan: Tianjin pian [The Architectural Heritage of
Modern China: Tianjin]. Beijing: Institute of Chinese modern Architecture \& Japanese Institute of Asian Modern Architecture.

\section{Publisher's Note}

Springer Nature remains neutral with regard to jurisdictional claims in published maps and institutional affiliations.

\section{Submit your manuscript to a SpringerOpen ${ }^{\circ}$ journal and benefit from:}

- Convenient online submission

- Rigorous peer review

- Open access: articles freely available online

High visibility within the field

- Retaining the copyright to your article

Submit your next manuscript at $\boldsymbol{\nabla}$ springeropen.com 